\title{
Changes in Socioeconomic Inequalities in Amenable Mortality after the Economic Crisis in Cities of the Spanish Mediterranean Coast
}

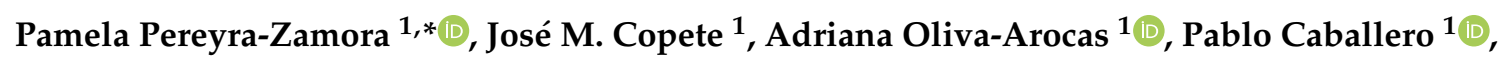 \\ Joaquín Moncho ${ }^{1}$, Carlos Vergara-Hernández ${ }^{2}$ (i) and Andreu Nolasco ${ }^{1}$ (i) \\ 1 Research Unit for the Analysis of Mortality and Health Statistics, Department of Community Nursing, \\ Preventive Medicine, Public Health and History of Science, University of Alicante, 03080 Alicante, Spain; \\ copetealacant@yahoo.co.uk (J.M.C.); adriana.oliva@ua.es (A.O.-A.); pablo.caballero@ua.es (P.C.); \\ joaquin.moncho@ua.es (J.M.); nolasco@ua.es (A.N.) \\ 2 Área de Desigualdades en Salud, Fundación para el Fomento de la Investigación Sanitaria y Biomédica de la \\ Comunitat Valenciana (FISABIO), 46035 Valencia, Spain; vergara_car@gva.es \\ * Correspondence: pamela.pereyra@ua.es
}

Received: 10 August 2020; Accepted: 4 September 2020; Published: 6 September 2020

\begin{abstract}
Several studies have described a decreasing trend in amenable mortality, as well as the existence of socioeconomic inequalities that affect it. However, their evolution, particularly in small urban areas, has largely been overlooked. The aim of this study is to analyse the socioeconomic inequalities in amenable mortality in three cities of the Valencian Community, namely, Alicante, Castellon, and Valencia, as well as their evolution before and after the start of the economic crisis (2000-2007 and 2008-2015). The units of analysis have been the census tracts and a deprivation index has been calculated to classify them according to their level of socioeconomic deprivation. Deaths and population were also grouped by sex, age group, period, and five levels of deprivation. The specific rates by sex, age group, deprivation level, and period were calculated for the total number of deaths due to all causes and amenable mortality and Poisson regression models were adjusted in order to estimate the relative risk. This study confirms that the inequalities between areas of greater and lesser deprivation in both all-cause mortality and amenable mortality persisted along the two study periods in the three cities. It also shows that these inequalities appear with greater risk of death in the areas of greatest deprivation, although not uniformly. In general, the risks of death from all causes and amenable mortality have decreased significantly from one period to the other, although not in all the groups studied. The evolution of death risks from before the onset of the crisis to the period after presented, overall, a general pro-cyclical trend. However, there are population subgroups for which the trend was counter-cyclical. The use of the deprivation index has made it possible to identify specific geographical areas with vulnerable populations in all three cities and, at the same time, to identify the change in the level of deprivation (ascending or descending) of the geographical areas throughout the two periods. It is precisely these areas where more attention is needed in order to reduce inequalities.
\end{abstract}

Keywords: mortality; amenable mortality; socioeconomic factors; economic recession; small-area analysis; Spain

\section{Introduction}

Amenable mortality (AM), understood as untimely and unjustified deaths that should not occur in the presence of timely healthcare procedures to avoid them, is a type of mortality used to assess the impact of the response and quality of a health system as well as the potential weaknesses of 
its healthcare. Thus, it has also been used during the last decades to evaluate the positive impact on a population's health due to the improvements in access, monitoring, diagnosis, and treatment, particularly in industrial countries [1,2].

For decades, in most European countries the trend of all-cause mortality has been decreasing [3]. Moreover, a progressive decrease in amenable mortality can also be observed in several of these countries at different rates, depending on the country and population group [4-6]. However, in some of the lower-income European countries, this trend has tended to change direction in recent years, particularly in the case of women [7].

In this context, the impact of the economic downturn on health, either due to worsening general socioeconomic conditions, or due to cutbacks in health services and public investment in health, or the privatization of health services, is the subject of a growing scientific literature, whose results are paradoxical. On the one hand, a series of studies indicate that mortality has a pro-cyclical behaviour against macroeconomic difficulties; that is, the recession, unemployment, etc., cause an improvement in certain healthy habits; such as quitting smoking, cooking at home, playing sports, or visiting family and friends that improve living conditions and reduce mortality, while economic booms increase mortality $[8,9]$. On the other hand, economic crises can exacerbate poverty levels or stress and therefore increase morbidity and mortality in a counter-cyclical trend. Sometimes pro-cyclical and counter-cyclical effects operate sequentially [10] or at different rhythms, in the short and long term [7]. Some authors who provide pro-cyclical results warn that while a recession can reduce death rates in the general population, they can worsen in specific social sectors or geographical areas [11]. This shows the need to study socioeconomic inequalities in health in general, and in mortality in particular [12,13].

Within this growing scientific interest, various studies have investigated the impact of the economic slowdown on the population's health and healthcare, both in Spain [14-16] and in other European countries [7,17-19], as well as in other continents [20,21]. The 2008 economic crisis coincided with the implementation of austerity policies that reduced the capacity of the Spanish public health system. This reduction struck unevenly depending on the position of the people and social groups in the social structure and depending on geographical location (rural/urban, centre/peripheral, outskirts, etc.). Therefore, as amenable mortality depends directly on the response capacity of the health system, its use is not only relevant as an indicator of the crisis impact, but also as an indicator of the inequalities of that impact at different socioeconomic or educational levels, sex/gender, age, ethnic group, or geographical area; so reveal recent studies in Spain [6,22] and Europe [23].

These inequalities in socioeconomic level or access to health services are in themselves a risk factor, and therefore it is necessary to study them in order to identify the most vulnerable groups or geographical areas to carry out specific interventions [24]. An adequate instrument to study health inequalities and the effects of economic downturns is the deprivation index (DI). Designed to measure the disadvantages of an individual, a family, or a group with regard to their community, or society, they are usually built from various indicators [25]. In Spain, a DI has been devised within the framework of the MEDEA projects [26]. This index, based on census data, has allowed the census tracts to be classified according to their level of socioeconomic deprivation, and its usefulness has been demonstrated in several studies on inequalities in mortality in urban areas $[19,27,28]$.

In Europe, some studies on socioeconomic inequalities in amenable mortality at the country level or comparisons between countries have been carried out $[4,29,30]$. However, few studies have researched these inequalities at the urban level, and there is no evidence that the changes in these inequalities have been studied after the start of the 2008 economic slowdown. Therefore, the objective of this article is to analyse the socioeconomic inequalities in amenable mortality in the three most important cities of the Valencian Community (Spain), and their evolution after the start of the 2008 economic crisis, taking the census tract as the basic geographic unit.

The main hypothesis is that the economic crisis did not affect all social groups in the same way. This differentiation in impact might depend on multiple factors, ranging from the duration of the crisis in the different economic areas to the position of the different census tracts in the socioeconomic 
structure, and that of the families and individuals that inhabit them; also, the different actors' responses (State, institutions, political parties, unions, families, and individuals) vis-a-vis the crisis and the crisis victims' needs.

\section{Materials and Methods}

\subsection{Design, Study Population, and Unit of Analysis}

This is an ecological analysis of AM comparing two periods: 2000-2007 and 2008-2015. The units of analysis were the census tracts (CTs) of the cities of Alicante (178 CTs), Castellon (58 CTs), and Valencia (531 CTs). A census tract, in the different countries where it is used, is the smallest territorial unit, established for operational purposes, for which statistical data is available. In Spain, a CT average population is 1000 inhabitants. These three cities are located in the Autonomous Community of Valencia, with an average annual total population (in all three cities) of 1,240,744 inhabitants during the period 2000-2007 and 1,310,123 in the period 2008-2015.

\subsection{Mortality Data}

All deaths of residents in these cities in the study periods have been included in the research. The death data were taken from the Mortality Registry of the Valencian Community, obtaining the variables year of death, age, sex, city (Alicante, Castellón, and Valencia), and cause of death. The causes of death used in the analysis were coded according to the International Classification of Diseases, Tenth Revision (ICD-10). The causes of amenable deaths analysed in the study were those proposed by Nolte and McKee [1] (see Table A1 of Appendix A), and following the criteria defined by these authors. It is important to notice that only $50 \%$ of the deaths due to ischaemic heart disease were included [2,31]. All deceases were georeferenced and assigned to their $\mathrm{CT}$ of residence. The data were obtained from an anonymized database maintained by the Mortality Registry of the Autonomous Community of Valencia. Since the study was based on retrospective administrative data, the approval of an ethics committee in Spain was not required.

\subsection{CTs by Socioeconomic Deprivation Level}

A deprivation index (DI) for each $\mathrm{CT}$, in all three cities and periods, was established using the following indicators (in percentage): (i) unemployment, (ii) manual workers, (iii) casual workers, (iv) insufficient education in young people (16 to 29 years), and (v) insufficient education in general. These indicators have already been proposed in the calculation of deprivation index (DI) on the basis of census data in major Spanish cities as the first component of a principal component analysis [26]. For our research, indicator data were obtained from the 2001 Population and Housing Census for the period 2000-2007, and from the 2011 Population and Housing Census for the period 2008-2015. The deprivation index used was developed within the framework of the MEDEA3 project (third edition of the national coordinated MEDEA project) from which the study data, both on socioeconomic inequality and mortality, stem.

For each period and city, the 10 (P10), 25 (P25), 75 (P75), and 90 (P90) DI percentiles were calculated. Thus, classifying the census tracts into five deprivation levels (DL) according to their value; that is, DL1, DI values lower than P10; DL2, DI values between P10 and P25; DL3, DI values between P25 and P75; DL4, DI values between P75 and P90; and DL5, DI values greater than P90.

Figure 1 shows the census tract distribution in the three cities in relation to their DL. This classification was outlined according to the aim of this research in order to quantify the difference in risks between the most socioeconomically favoured areas (DL1) and those of greatest deprivation (DL5). Table A2 of Appendix A shows the average values of the five socioeconomic indicators used in the different DLs of each city and period under study. In addition, the DI calculated for the two periods has made visible the changes that have occurred over time in the three cities (see Figure 1). 


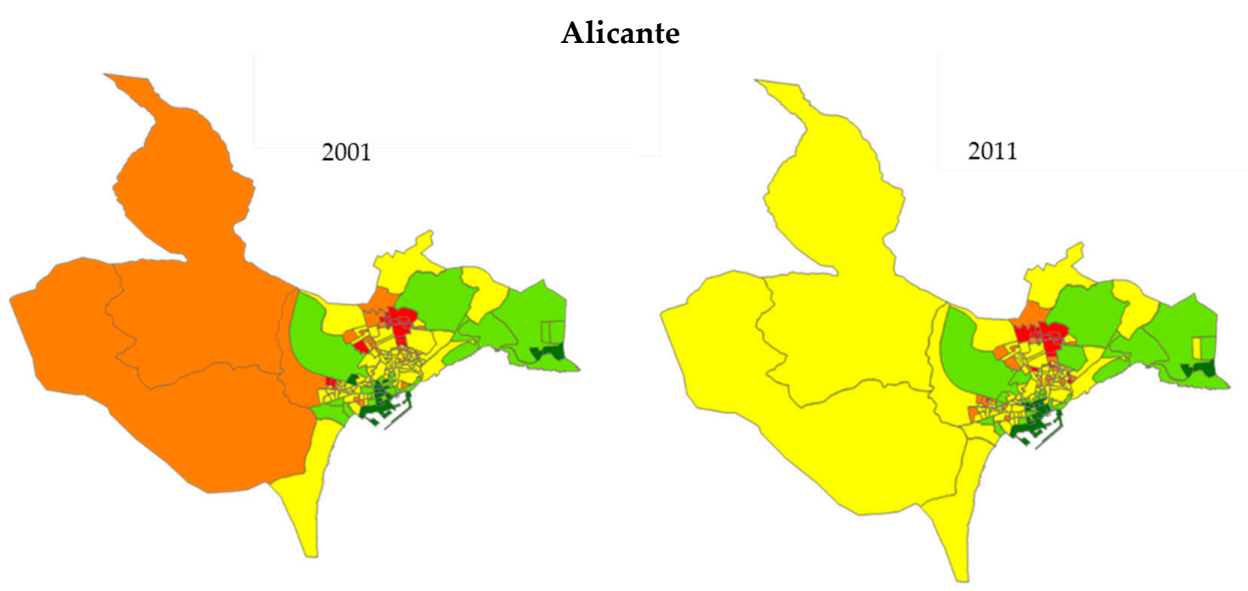

\section{Castellón}
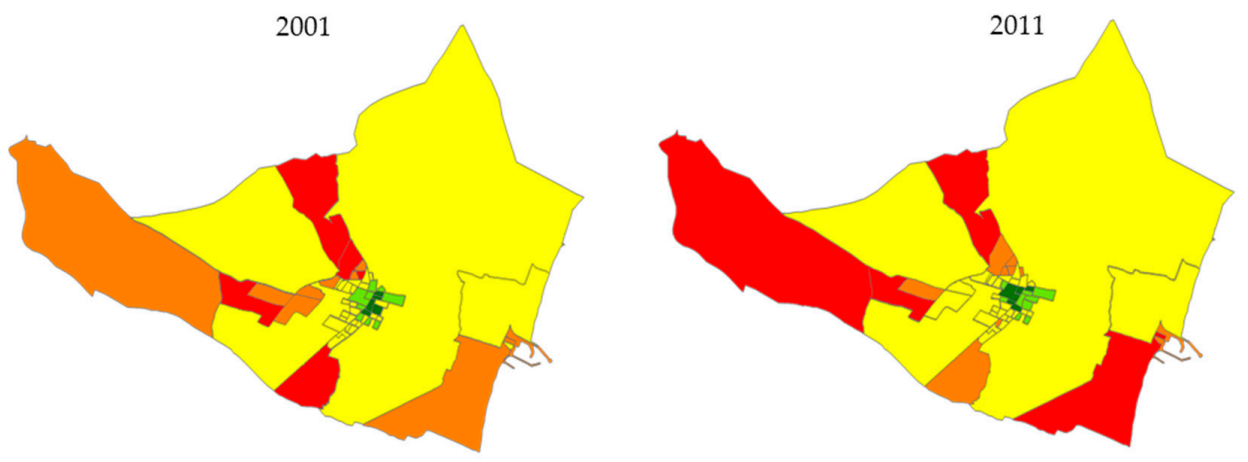

Valencia
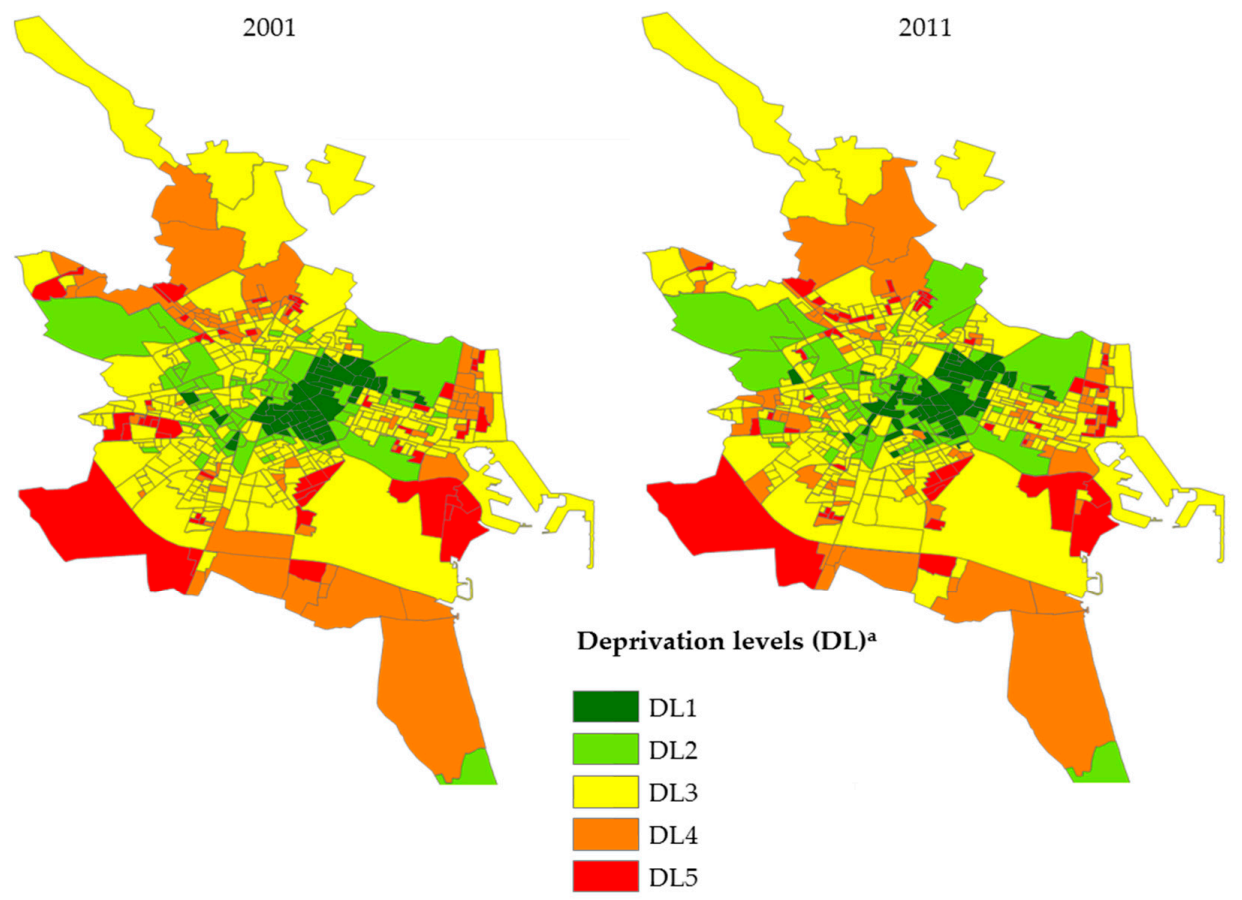

Figure 1. Geographical distribution of the five levels of deprivation (DL) according to census tracts in the cities of Alicante, Castellón, and Valencia (2001 and 2011). 


\subsection{Population Data}

The population data (by CT, year, age, and sex) used in order to calculate mortality indicators (rates and the relative risks) for the periods studied were obtained with permission from the Valencian Institute of Statistics, which is responsible for compiling population statistics in this region. Table A3 of Appendix A shows the average annual population for all the cities under study by sex, age group, $\mathrm{DL}$, and period.

\subsection{Data Analysis}

To study the evolution of the risk of death over time, the data were classified into two periods: 2000-2007 (P1) and 2008-2015 (P2). Deaths were also grouped by three age ranges: 0-44, 45-64, and 65 and older.

The specific rates by sex, age group, DL, and period have been calculated for the total number of deaths due to all causes and the total amenable mortality. In order to estimate the relative risks (RRs) between the categories of the variables under study, the Poisson regression models also have been adjusted, taking into consideration the city, age, DL, and period effects, separated by sex, and carrying out a robust estimation to control the possible over-dispersion of the data. In addition, the proportional mortality of the large ICD-10 groups was calculated according to sex and deprivation level for all three cities so as to compare the pattern of mortality by groups of causes according to period. Finally, the program IBM ${ }^{\circledR}$ SPSS $^{\circledR}$ Statistics (v.25) (Armonk, NY, USA) and our own software were used for calculating the mortality indicators.

\section{Results}

Between 2000 and 2015 there occurred 177,583 deaths in all three cities under study $(40,774$ in Alicante, 20,935 in Castellón, and 115,874 in Valencia). Nevertheless, 2634 of these (1.5\%) could not be georeferenced and assigned to the census section of residence as the deceased person's residence address was not stated or did not correspond to the cities under study. Regarding the remaining 174,949 that could be georeferenced, 86,479 occurred in the period 2000-2007 and 88,470 in 2008-2015. Tables A4 and A5 of Appendix A show the death frequencies and percentages for the specific causes of amenable mortality and the chapters of the ICD-10, according to period, DL, and sex.

In Table 1, the average values and confidence interval of the DI are displayed. In it, it can be seen that the average values per DI varied scarcely from the period 2000-2007 to the period 2008-2015. The city of Castellón, for instance, showed smaller differences in the averages observed between the more extreme DLs, but similar in the rest of DLs. The table also includes the number of sections for each of the DLs in each city and all cities as a whole. Observing Table A2 of Appendix A, it can be noticed that areas with DL5 are areas with an alarming situation, where all the indicators used to build the index appear in high values: areas hit by unemployment, lack of training, school dropout, precarious work, and so on.

In order to verify if the effects of DL, period, and age group on mortality risk were significantly different according to city, the Poisson models were adjusted, including the effects of the following variables: city, DL, period, age group, and the interactions between the city and the rest of the other variables, verifying the absence of statistical significance of the terms of the interaction of the city effect with the other effects.

All interactions were not significant for both all-cause mortality (in men, $p=0.569$ interaction with DL, $p=0.195$ with period and $p=0.160$ with age; in women $p=0.491$ with DL, $p=0.070$ with period and $p=0.101$ with age) and mortality due to amenable causes (in men, $p=0.711$ interaction with DL, $p=0.186$ with period and $p=0.599$ with age; in women $p=0.771$ with $\mathrm{DL}, p=0.632$ with period and $p=0.072$ with age). Due to the absence of a significant interaction, the estimation of effects was carried out jointly for the three cities under study. 
Table 1. Descriptive characteristics of the deprivation index according to deprivation levels for the census sections of each city and all three cities.

\begin{tabular}{|c|c|c|c|c|c|c|c|c|}
\hline \multirow{3}{*}{ Town } & \multirow{3}{*}{$\begin{array}{l}\text { Deprivation } \\
\text { Level (DL) }^{a}\end{array}$} & \multirow{3}{*}{$\begin{array}{c}\text { Number of } \\
\text { Census } \\
\text { Tract }\end{array}$} & \multicolumn{3}{|c|}{ 2008-2015 (2011 Census) } & \multicolumn{3}{|c|}{ 2000-2007 (2001 Census) } \\
\hline & & & \multirow[b]{2}{*}{ Mean } & \multicolumn{2}{|c|}{$95 \% \mathrm{CI}$} & \multirow[b]{2}{*}{ Mean } & \multicolumn{2}{|c|}{$95 \% \mathrm{CI}$} \\
\hline & & & & $\begin{array}{l}\text { Lower } \\
\text { Limit }\end{array}$ & $\begin{array}{l}\text { Upper } \\
\text { Limit }\end{array}$ & & $\begin{array}{l}\text { Lower } \\
\text { Limit }\end{array}$ & $\begin{array}{l}\text { Upper } \\
\text { Limit }\end{array}$ \\
\hline \multirow{6}{*}{ Alicante } & DL1 & 17 & -0.84 & -0.88 & -0.79 & -0.80 & -0.85 & -0.76 \\
\hline & DL2 & 27 & -0.56 & -0.60 & -0.52 & -0.52 & -0.56 & -0.47 \\
\hline & DL3 & 90 & 0.00 & -0.04 & 0.04 & 0.01 & -0.03 & 0.05 \\
\hline & DL4 & 27 & 0.44 & 0.40 & 0.47 & 0.42 & 0.38 & 0.46 \\
\hline & DL5 & 17 & 1.03 & 0.80 & 1.25 & 0.92 & 0.77 & 1.06 \\
\hline & Total & 178 & 0.00 & -0.08 & 0.08 & 0.00 & -0.07 & 0.07 \\
\hline \multirow{6}{*}{ Castellón } & DL1 & 5 & -0.55 & -0.60 & -0.49 & -0.67 & -0.80 & -0.54 \\
\hline & DL2 & 9 & -0.41 & -0.45 & -0.37 & -0.41 & -0.45 & -0.38 \\
\hline & DL3 & 30 & -0.01 & -0.08 & 0.06 & -0.03 & -0.10 & 0.03 \\
\hline & DL4 & 9 & 0.41 & 0.37 & 0.45 & 0.47 & 0.38 & 0.55 \\
\hline & DL5 & 5 & 0.61 & 0.48 & 0.74 & 0.77 & 0.55 & 0.98 \\
\hline & Total & 58 & 0.00 & -0.10 & 0.10 & 0.00 & -0.11 & 0.11 \\
\hline \multirow{6}{*}{ Valencia } & DL1 & 53 & -0.72 & -0.74 & -0.70 & -0.78 & -0.80 & -0.75 \\
\hline & DL2 & 79 & -0.49 & -0.51 & -0.47 & -0.50 & -0.52 & -0.48 \\
\hline & DL3 & 266 & -0.01 & -0.04 & 0.01 & 0.00 & -0.02 & 0.03 \\
\hline & DL4 & 80 & 0.44 & 0.42 & 0.46 & 0.46 & 0.44 & 0.47 \\
\hline & DL5 & 53 & 0.85 & 0.80 & 0.91 & 0.82 & 0.77 & 0.87 \\
\hline & Total & 531 & 0.00 & -0.04 & 0.04 & 0.00 & -0.04 & 0.04 \\
\hline \multirow{6}{*}{$\begin{array}{l}\text { All cities } \\
\text { together }\end{array}$} & DL1 & 75 & -0.74 & -0.76 & -0.71 & -0.78 & -0.80 & -0.75 \\
\hline & DL2 & 115 & -0.50 & -0.52 & -0.48 & -0.50 & -0.51 & -0.48 \\
\hline & DL3 & 386 & -0.01 & -0.03 & 0.01 & 0.00 & -0.02 & 0.02 \\
\hline & DL4 & 116 & 0.44 & 0.42 & 0.45 & 0.45 & 0.43 & 0.46 \\
\hline & DL5 & 75 & 0.88 & 0.81 & 0.94 & 0.84 & 0.79 & 0.89 \\
\hline & Total & 767 & 0.00 & -0.03 & 0.03 & 0.00 & -0.03 & 0.03 \\
\hline
\end{tabular}

${ }^{a}$ DL: Deprivation level of the census tract of residence based on the deprivation index (DI). DL1: DI < P10; DL2:

P10 $\leq$ DI < P25; DL3: P25 $\leq$ DI < P75; DL4: P75 $\leq$ DI < P90; DL5: DI $\geq$ P90. P $_{\mathrm{q}}=$ Percentile $q$.

In the joint analysis of the three cities, the Poisson regression models were adjusted by sex. These included the effects of the following variables: DL, period, age group, the first-level interactions between DL and the rest of the other variables, and also the second-level interaction between DL, period, and age. These models suggested the existence of a significant $(p<0.05)$ second-level interaction between the DL effect, period, and age group in both men and women. Figures 2 and 3 show the specific rates by sex, age group, period, and DL for all causes and amenable mortality (the values of the rates can be observed in Tables A6 and A7 of Appendix A).

Mortality graphs for overall and amenable mortality suggest that the mortality rates are generally higher at the levels of greatest economic deprivation. The detected interaction could be due to some exceptions to this general behaviour. Thus, for general mortality in men in the age group of over 65 there are hardly any differences in rates according to the DL in the period 2000-2007, while, on the contrary, regarding amenable mortality in men aged 0-44 years, there are. In women, the age group 65 and over has not experienced increases in rates according to the DL for general mortality in any period, unlike for amenable mortality.

Due to the existence of an interaction, the relative risks between categories of DL (a measure of inequality according to DL) specific by sex, age, and period were estimated using a simple Poisson model with DL as the only effect. To estimate the increase or decrease in the risks of death of one to another period, a simple Poisson model specific by sex, age, and DL was adjusted with period as the only effect. 
Men
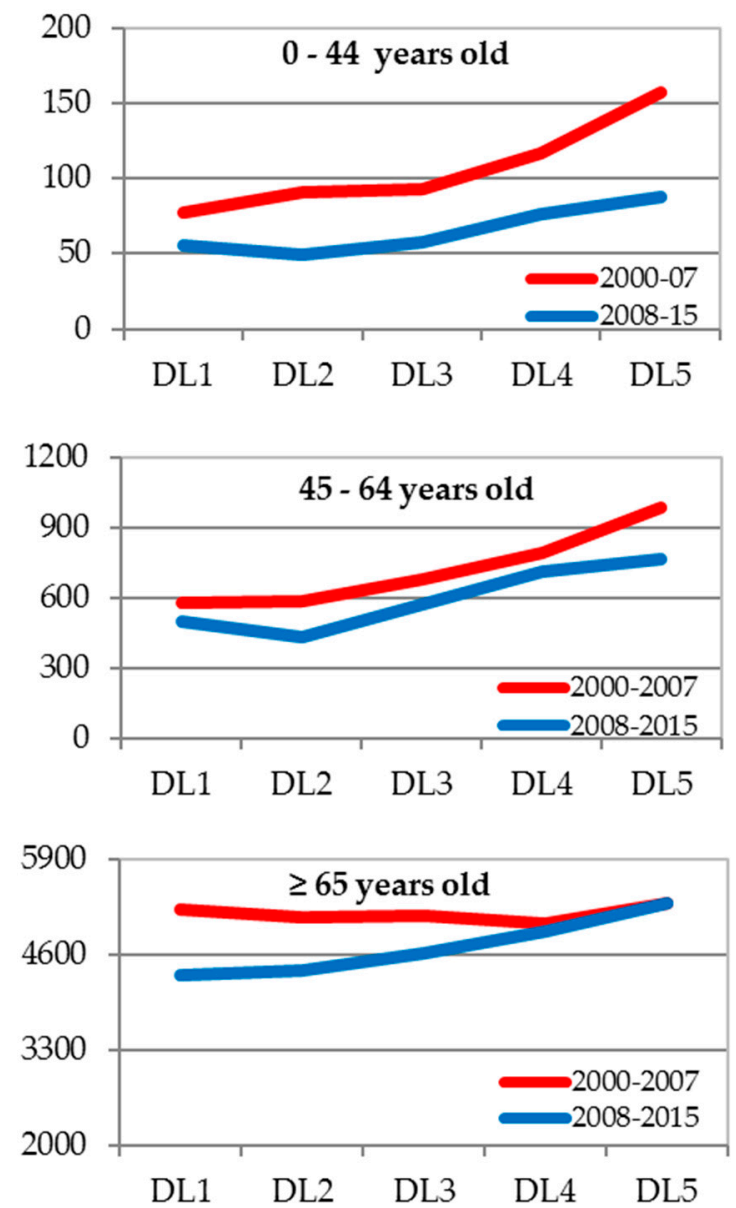

Women
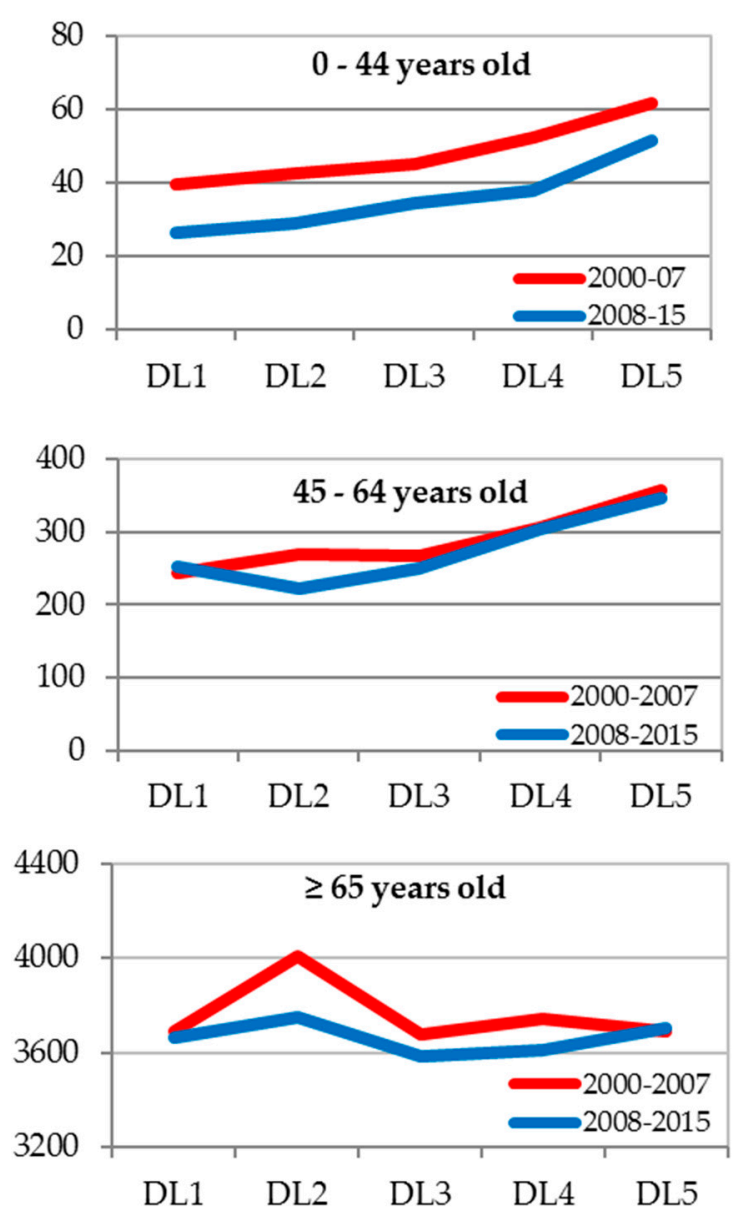

Figure 2. Specific mortality rates for all causes $(\times 100,000)$ by sex, age, and deprivation level (DL). Alicante, Castellón, and Valencia jointly 2009-2015. DL: Deprivation level for the census tract of residence based on the deprivation index (DI). DL1: DI $<\mathrm{P}_{10}$; DL2: $\mathrm{P}_{10} \leq \mathrm{DI}<\mathrm{P}_{25}$; DL3: $\mathrm{P}_{25} \leq \mathrm{DI}<$ $\mathrm{P}_{75}$; DL4: $\mathrm{P}_{75} \leq \mathrm{DI}<\mathrm{P}_{90}$; DL5: DI $\geq \mathrm{P}_{90}$. $\mathrm{P}_{\mathrm{q}}=$ Percentile $\mathrm{q}$.

Regarding mortality from all causes, as Table 2 shows, the risk of death increased as the DL worsened, in the younger age groups (0-44 and 45-64 years), both in men and women (the significant RRs were greater than 1 in the highest categories, DL5 and DL4, when compared with DL1), and both in the first and second period under study. Nevertheless, in the 0-44 age group, the RRs were higher for men in the first period and women in the second, suggesting a tendency towards decreasing inequalities in men and increasing in women. The behaviour of the mortality risks in the age group of 65 years of age and over was different, since only the RRs significantly higher than 1 occurred in men in the second period, whereas regarding women only the relative risk of the DL2 group was significantly higher in the first period. Regarding the evolution from the first to the second period, overall, the risk of death decreased, with the RRs adjusted by age in the second period as compared to the first period of 0.875 (95\% CI: 0.833-0.919) in men and 0.961 (95\% CI: 0.945-0.977) in women. 
Men
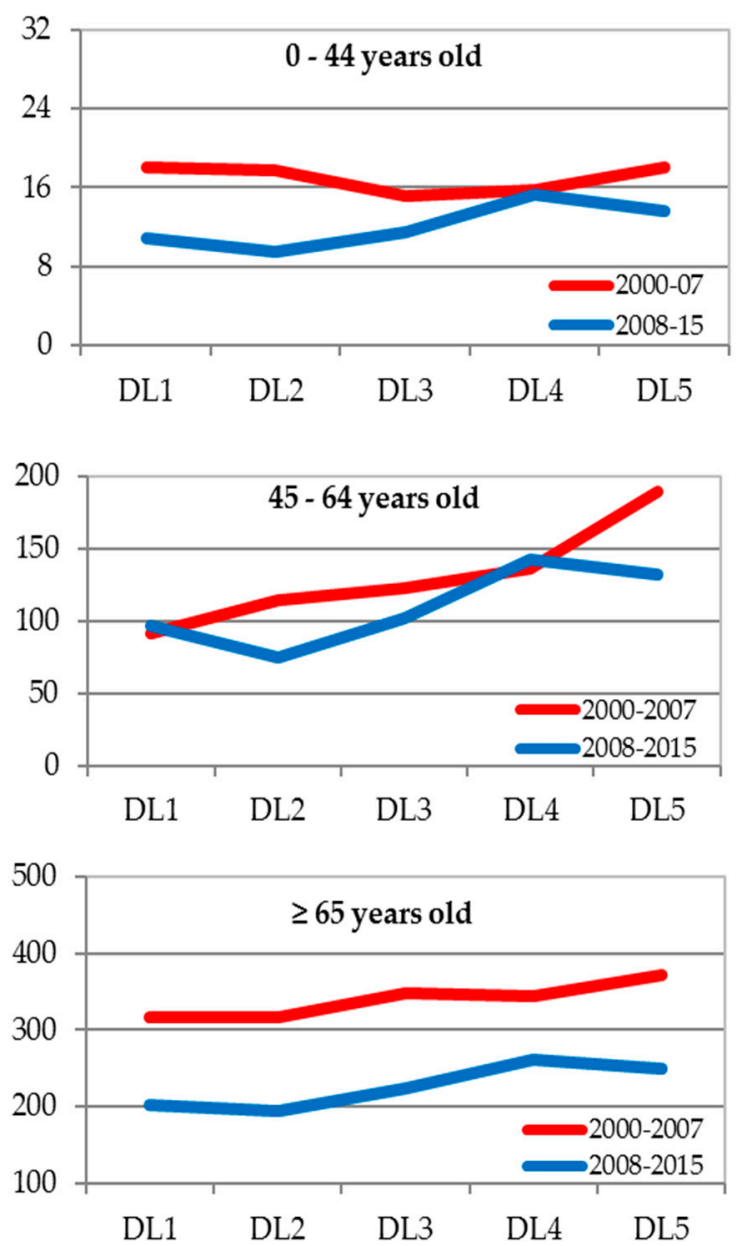

Women
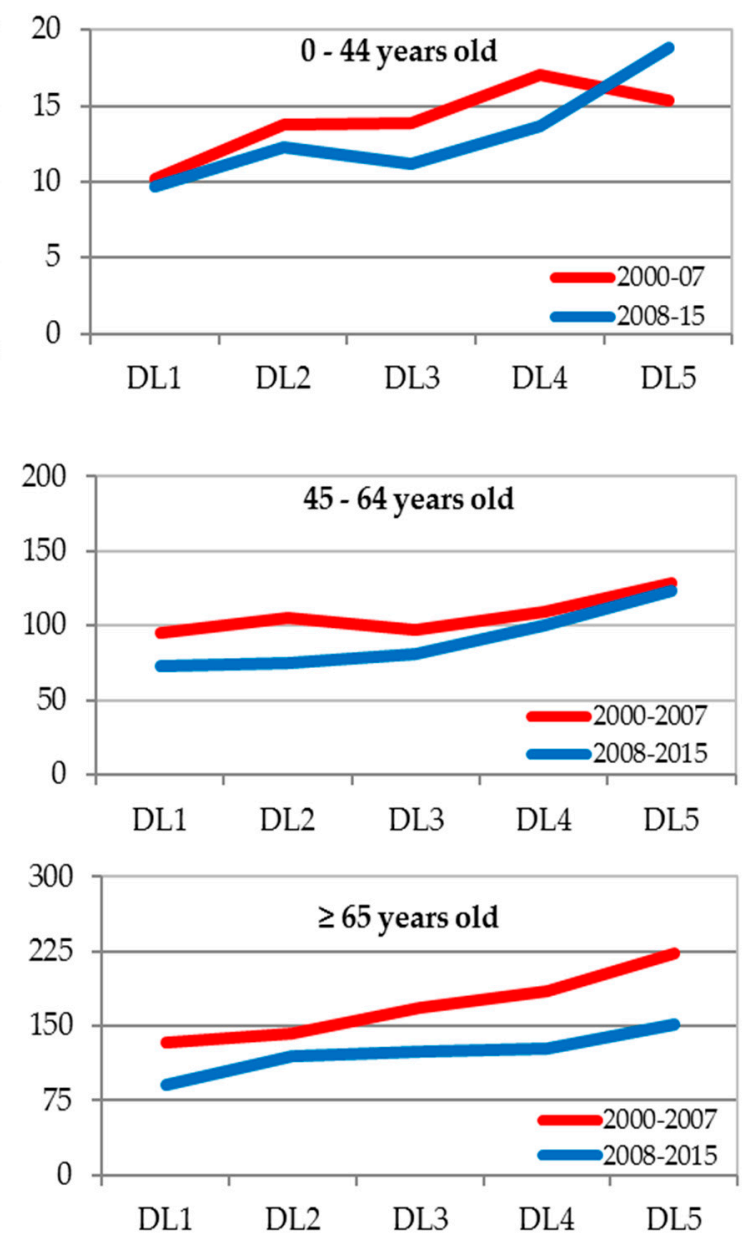

Figure 3. Specific mortality rates for amenable causes $(\times 100,000)$ by sex, age, and deprivation level $(\mathrm{DL})^{\mathrm{a}}$. Alicante, Castellón, and Valencia jointly 2009-2015. DL: Deprivation level for the census tract of residence based on the deprivation index (DI). DL1: DI < P10; DL2: P10 $\leq$ DI < P25; DL3: P25 $\leq$ DI < P75; DL4: P75 $\leq$ DI < P90; DL5: DI $\geq$ P90. $\mathrm{P}_{\mathrm{q}}=$ Percentile $\mathrm{q}$.

Table 3 shows the RR of the 2008-2015 period vis-a-vis the 2000-2007 period. In men, a significant overall decrease in the risk of death in all categories of DL (except in DL4 and DL5 for the age group of 65 and over) can be seen. However, there was no significant drop in the risk of death at levels DL4 (ages 45-64 and 65 and more) and DL5 (all ages) and in DL1 (ages 45-64 and 65 and more) in women and in DL5 and DL4 (age 65 and over) in men. This means that men and women of these age groups and DL did not improve the risk of death from all causes.

Regarding mortality due to amenable causes, according to Table 4, the risks of death increased in women, for any age, in both periods, as the DL worsened. However, in men, the behaviour of this variable was different depending on the age group. In the group of 0-44 years of age, the RRs went from being lower than 1 (therefore lower risk of death in any category of DL than in DL1) in the first period to RRs greater than 1 in the worst DL categories (DL5 and DL4) in the second period. Although this suggests a tendency to increase inequality, these results were not significant. In addition, in the intermediate age group (45-64 years), the RRs were significantly higher than 1 in the most deprived DL categories (DL5 and DL4) in both periods. Finally, in the group of seniors (65 and over), the RRs increased slightly in the second period. 
Table 2. Relative risk of death for all causes according to the level of deprivation and $95 \%$ confidence intervals $(95 \% \mathrm{CI})$ specific by age, sex, and period.

\begin{tabular}{|c|c|c|c|c|c|c|c|c|}
\hline \multirow{3}{*}{ Sex } & \multirow{3}{*}{ Age } & \multirow{3}{*}{$\begin{array}{l}\text { Deprivation } \\
\text { Level (DL) }^{a}\end{array}$} & \multicolumn{3}{|c|}{ 2000-2007 } & \multicolumn{3}{|c|}{ 2008-2015 } \\
\hline & & & \multirow{2}{*}{$\mathbf{R R}$} & \multicolumn{2}{|c|}{$95 \%$ CI } & \multirow{2}{*}{ RR } & \multicolumn{2}{|c|}{$95 \%$ CI } \\
\hline & & & & Lower & Upper & & Lower & Upper \\
\hline \multirow{15}{*}{ Men } & \multirow{5}{*}{$0-44$} & DL5 & 2.034 & 1.708 & 2.434 & 1.582 & 1.263 & 1.997 \\
\hline & & DL4 & 1.504 & 1.269 & 1.793 & 1.365 & 1.097 & 1.713 \\
\hline & & DL3 & 1.196 & 1.024 & 1.406 & 1.040 & 0.853 & 1.282 \\
\hline & & DL2 & 1.168 & 0.981 & 1.397 & 0.881 & 0.705 & 1.110 \\
\hline & & DL1 & 1 & . & . & 1 & . & . \\
\hline & \multirow{5}{*}{$45-64$} & DL5 & 1.697 & 1.525 & 1.890 & 1.535 & 1.369 & 1.724 \\
\hline & & DL4 & 1.372 & 1.242 & 1.519 & 1.427 & 1.283 & 1.591 \\
\hline & & DL3 & 1.168 & 1.068 & 1.279 & 1.146 & 1.041 & 1.264 \\
\hline & & DL2 & 1.009 & 0.911 & 1.119 & 0.871 & 0.781 & 0.974 \\
\hline & & DL1 & 1 & . & . & 1 & . & . \\
\hline & \multirow{5}{*}{$\geq 65$} & DL5 & 1.015 & 0.966 & 1.066 & 1.226 & 1.166 & 1.289 \\
\hline & & DL4 & 0.963 & 0.920 & 1.008 & 1.135 & 1.083 & 1.190 \\
\hline & & DL3 & 0.983 & 0.945 & 1.023 & 1.068 & 1.025 & 1.113 \\
\hline & & DL2 & 0.979 & 0.935 & 1.025 & 1.014 & 0.968 & 1.062 \\
\hline & & DL1 & 1 & . & . & 1 & . & . \\
\hline \multirow{15}{*}{ Women } & \multirow{5}{*}{$0-44$} & DL5 & 1.557 & 1.202 & 2.030 & 1.933 & 1.401 & 2.711 \\
\hline & & DL4 & 1.327 & 1.041 & 1.706 & 1.422 & 1.037 & 1.984 \\
\hline & & DL3 & 1.142 & 0.922 & 1.434 & 1.294 & 0.977 & 1.756 \\
\hline & & DL2 & 1.074 & 0.841 & 1.383 & 1.096 & 0.802 & 1.524 \\
\hline & & DL1 & 1 & . & . & 1 & . & . \\
\hline & \multirow{5}{*}{$45-64$} & DL5 & 1.473 & 1.257 & 1.727 & 1.372 & 1.174 & 1.606 \\
\hline & & DL4 & 1.262 & 1.092 & 1.463 & 1.198 & 1.038 & 1.386 \\
\hline & & DL3 & 1.102 & 0.971 & 1.254 & 0.989 & 0.873 & 1.124 \\
\hline & & DL2 & 1.113 & 0.964 & 1.287 & 0.882 & 0.765 & 1.018 \\
\hline & & DL1 & 1 & . & . & 1 & . & . \\
\hline & \multirow{5}{*}{$\geq 65$} & DL5 & 1.000 & 0.955 & 1.048 & 1.010 & 0.964 & 1.058 \\
\hline & & DL4 & 1.015 & 0.972 & 1.060 & 0.986 & 0.945 & 1.028 \\
\hline & & DL3 & 0.996 & 0.960 & 1.034 & 0.978 & 0.944 & 1.014 \\
\hline & & DL2 & 1.087 & 1.042 & 1.133 & 1.024 & 0.983 & 1.067 \\
\hline & & DL1 & 1 & . & . & 1 & . & . \\
\hline
\end{tabular}

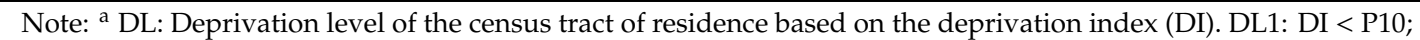
DL2: P10 $\leq$ DI < P25; DL3: P25 $\leq$ DI < P75; DL4: P75 $\leq$ DI < P90; DL5: DI $\geq$ P90. $\mathrm{P}_{\mathrm{q}}=$ Percentile .

Comparing period 2008-2015 with period 2000-2007, it can be seen that the risk of death decreased, with RRs adjusted by age of 0.725 (CI95\%: 0.659-0.798) in men and 0.785 (C195\%: 0.741-0.831) in women. Table 5 shows the RRs of the period 2008-2015 as compared to the period 2000-2007. A significant reduction in the risks of death in most of the DL categories can be observed, although with some exceptions, since no significant drop was observed in men of 0-44 years of age in DL1, DL4, and DL5 and of 45-65 years in DL1 and DL4, nor in women of 0-44 years in DL1, DL2, and DL4 and of 45-65 years in DL1, DL4, and DL5. In addition, there was an upsurge (not significant) in the risk of death (RR > 1) at the DL4 level in men of 45-64 years and in DL5 in women of 0-44 years. 
Table 3. Relative risk of death for all causes in the 2008-2015 period versus the 2000-2007 period and $95 \%$ confidence intervals ( $95 \% \mathrm{CI}$ ) specific for age, sex, and deprivation level.

\begin{tabular}{|c|c|c|c|c|c|c|c|}
\hline \multirow{3}{*}{$\begin{array}{l}\text { Deprivation } \\
\text { Level (DL) }^{a}\end{array}$} & \multirow{3}{*}{ Age } & \multicolumn{3}{|c|}{ Men } & \multicolumn{3}{|c|}{ Women } \\
\hline & & \multirow{2}{*}{ RR } & \multicolumn{2}{|c|}{$95 \%$ CI } & \multirow{2}{*}{$\mathbf{R R}$} & \multicolumn{2}{|c|}{$95 \%$ CI } \\
\hline & & & Lower & Upper & & Lower & Upper \\
\hline \multirow{3}{*}{ DL1 } & $0-44$ & 0.720 & 0.562 & 0.918 & 0.671 & 0.470 & 0.946 \\
\hline & $45-64$ & 0.863 & 0.761 & 0.977 & 1.042 & 0.882 & 1.232 \\
\hline & $\geq 65$ & 0.829 & 0.786 & 0.874 & 0.993 & 0.947 & 1.041 \\
\hline \multirow{3}{*}{ DL2 } & $0-44$ & 0.543 & 0.467 & 0.631 & 0.684 & 0.556 & 0.840 \\
\hline & $45-64$ & 0.745 & 0.684 & 0.811 & 0.826 & 0.736 & 0.927 \\
\hline & $\geq 65$ & 0.859 & 0.826 & 0.892 & 0.935 & 0.904 & 0.968 \\
\hline \multirow{3}{*}{ DL3 } & $0-44$ & 0.626 & 0.577 & 0.680 & 0.760 & 0.678 & 0.851 \\
\hline & $45-64$ & 0.846 & 0.810 & 0.885 & 0.936 & 0.876 & 0.999 \\
\hline & $\geq 65$ & 0.901 & 0.882 & 0.920 & 0.975 & 0.956 & 0.995 \\
\hline \multirow{3}{*}{ DL4 } & $0-44$ & 0.654 & 0.568 & 0.751 & 0.718 & 0.582 & 0.885 \\
\hline & $45-64$ & 0.897 & 0.829 & 0.970 & 0.990 & 0.878 & 1.115 \\
\hline & $\geq 65$ & 0.977 & 0.940 & 1.016 & 0.964 & 0.929 & 1.001 \\
\hline \multirow{3}{*}{ DL5 } & $0-44$ & 0.560 & 0.479 & 0.653 & 0.832 & 0.657 & 1.053 \\
\hline & $45-64$ & 0.780 & 0.709 & 0.859 & 0.972 & 0.838 & 1.127 \\
\hline & $\geq 65$ & 1.002 & 0.957 & 1.049 & 1.002 & 0.958 & 1.049 \\
\hline
\end{tabular}

Note: ${ }^{a}$ DL: Deprivation level for the census tract of residence based on the deprivation index (DI). DL1: DI $<\mathrm{P}_{10}$; DL2: $\mathrm{P}_{10} \leq \mathrm{DI}<\mathrm{P}_{25}$; DL3: $\mathrm{P}_{25} \leq \mathrm{DI}<\mathrm{P}_{75} ;$ DL4: $\mathrm{P}_{75} \leq \mathrm{DI}<\mathrm{P}_{90}$; DL5: DI $\geq \mathrm{P}_{90}$. $\mathrm{P}_{\mathrm{q}}=$ Percentile $\mathrm{q}$.

Table 4. Relative risk of death by amenable causes of death according to deprivation level and $95 \%$ confidence intervals (95\% CI) specific for age, sex, and period.

\begin{tabular}{|c|c|c|c|c|c|c|c|c|}
\hline \multirow{3}{*}{ Sex } & \multirow{3}{*}{ Age } & \multirow{3}{*}{$\begin{array}{l}\text { Deprivation } \\
\text { Level (DL) }^{a}\end{array}$} & \multicolumn{3}{|c|}{ 2000-2007 } & \multicolumn{3}{|c|}{ 2008-2015 } \\
\hline & & & \multirow{2}{*}{$\mathbf{R R}$} & \multicolumn{2}{|c|}{$95 \% \mathrm{CI}$} & \multirow{2}{*}{$\mathbf{R R}$} & \multicolumn{2}{|c|}{$95 \%$ CI } \\
\hline & & & & Lower & Upper & & Lower & Upper \\
\hline \multirow{15}{*}{ Men } & \multirow{5}{*}{$0-44$} & DL5 & 0.997 & 0.659 & 1.519 & 1.256 & 0.742 & 2.195 \\
\hline & & DL4 & 0.869 & 0.593 & 1.292 & 1.419 & 0.876 & 2.405 \\
\hline & & DL3 & 0.835 & 0.605 & 1.183 & 1.061 & 0.686 & 1.736 \\
\hline & & DL2 & 0.979 & 0.678 & 1.437 & 0.884 & 0.538 & 1.514 \\
\hline & & DL1 & 1 & . & . & 1 & . & . \\
\hline & \multirow{5}{*}{ 45-64 } & DL5 & 2.079 & 1.607 & 2.710 & 1.364 & 1.046 & 1.789 \\
\hline & & DL4 & 1.491 & 1.165 & 1.925 & 1.474 & 1.160 & 1.891 \\
\hline & & DL3 & 1.345 & 1.080 & 1.696 & 1.049 & 0.846 & 1.318 \\
\hline & & DL2 & 1.254 & 0.979 & 1.620 & 0.775 & 0.602 & 1.005 \\
\hline & & DL1 & 1 & . & . & 1 & . & . \\
\hline & \multirow{5}{*}{$\geq 65$} & DL5 & 1.177 & 0.971 & 1.429 & 1.238 & 0.983 & 1.564 \\
\hline & & DL4 & 1.090 & 0.910 & 1.311 & 1.297 & 1.052 & 1.608 \\
\hline & & DL3 & 1.099 & 0.939 & 1.294 & 1.112 & 0.925 & 1.350 \\
\hline & & DL2 & 1.002 & 0.834 & 1.209 & .960 & 0.774 & 1.196 \\
\hline & & DL1 & 1 & . & . & 1 & . & . \\
\hline
\end{tabular}


Table 4. Cont.

\begin{tabular}{|c|c|c|c|c|c|c|c|c|}
\hline \multirow{3}{*}{ Sex } & \multirow{3}{*}{ Age } & \multirow{3}{*}{$\begin{array}{l}\text { Deprivation } \\
\text { Level (DL) }^{a}\end{array}$} & \multicolumn{3}{|c|}{$2000-2007$} & \multicolumn{3}{|c|}{ 2008-2015 } \\
\hline & & & \multirow{2}{*}{$\mathbf{R R}$} & \multicolumn{2}{|c|}{$95 \%$ CI } & \multirow{2}{*}{ RR } & \multicolumn{2}{|c|}{$95 \%$ CI } \\
\hline & & & & Lower & Upper & & Lower & Upper \\
\hline \multirow{15}{*}{ Women } & \multirow{5}{*}{$0-44$} & DL5 & 1.507 & 0.905 & 2.564 & 1.932 & 1.143 & 3.413 \\
\hline & & DL4 & 1.673 & 1.063 & 2.735 & 1.405 & 0.840 & 2.464 \\
\hline & & DL3 & 1.364 & 0.908 & 2.154 & 1.148 & 0.727 & 1.931 \\
\hline & & DL2 & 1.345 & 0.851 & 2.205 & 1.268 & 0.772 & 2.195 \\
\hline & & DL1 & 1 & . & . & 1 & . & . \\
\hline & \multirow{5}{*}{$45-64$} & DL5 & 1.347 & 1.040 & 1.748 & 1.696 & 1.286 & 2.250 \\
\hline & & DL4 & 1.153 & 0.912 & 1.466 & 1.378 & 1.064 & 1.801 \\
\hline & & DL3 & 1.016 & 0.831 & 1.254 & 1.110 & 0.885 & 1.411 \\
\hline & & DL2 & 1.109 & 0.883 & 1.402 & 1.033 & 0.801 & 1.346 \\
\hline & & DL1 & 1 & . & . & 1 & . & . \\
\hline & \multirow{5}{*}{$\geq 65$} & DL5 & 1.665 & 1.338 & 2.083 & 1.665 & 1.284 & 2.173 \\
\hline & & DL4 & 1.384 & 1.118 & 1.723 & 1.394 & 1.089 & 1.798 \\
\hline & & DL3 & 1.251 & 1.037 & 1.523 & 1.367 & 1.102 & 1.718 \\
\hline & & DL2 & 1.062 & 0.853 & 1.330 & 1.309 & 1.026 & 1.684 \\
\hline & & DL1 & 1 & . & . & 1 & . & . \\
\hline
\end{tabular}

Note: ${ }^{a}$ DL: Deprivation level of the census tract of residence based on the deprivation index (DI). DL1: DI $<\mathrm{P}_{10}$; DL2: $\mathrm{P}_{10} \leq \mathrm{DI}<\mathrm{P}_{25}$; DL3: $\mathrm{P}_{25} \leq \mathrm{DI}<\mathrm{P}_{75}$; DL4: $\mathrm{P}_{75} \leq \mathrm{DI}<\mathrm{P}_{90}$; DL5: DI $\geq \mathrm{P}_{90}$. $\mathrm{P}_{\mathrm{q}}=$ Percentile $\mathrm{q}$.

Table 5. Relative risk of death for amenable causes of death in the 2008-2015 period versus the 2000-2007 period and 95\% confidence intervals (95\% CI) specific by age, sex, and deprivation level.

\begin{tabular}{|c|c|c|c|c|c|c|c|}
\hline \multirow{3}{*}{$\begin{array}{l}\text { Deprivation } \\
\text { Level (DL) }^{a}\end{array}$} & \multirow{3}{*}{ Age } & \multicolumn{3}{|c|}{ Men } & \multicolumn{3}{|c|}{ Women } \\
\hline & & \multirow{2}{*}{$\mathbf{R R}$} & \multicolumn{2}{|c|}{$95 \%$ CI } & \multirow{2}{*}{$\mathbf{R R}$} & \multicolumn{2}{|c|}{$95 \% \mathrm{CI}$} \\
\hline & & & Lower & Upper & & Lower & Upper \\
\hline \multirow{3}{*}{ DL1 } & $0-44$ & 0.598 & 0.343 & 1.010 & 0.953 & 0.508 & 1.761 \\
\hline & $45-64$ & 1.060 & 0.786 & 1.429 & 0.765 & 0.571 & 1.021 \\
\hline & $\geq 65$ & 0.640 & 0.507 & 0.806 & 0.681 & 0.516 & 0.896 \\
\hline \multirow{3}{*}{ DL2 } & $0-44$ & 0.540 & 0.382 & 0.757 & 0.899 & 0.641 & 1.260 \\
\hline & $45-64$ & 0.655 & 0.536 & 0.799 & 0.713 & 0.589 & 0.863 \\
\hline & $\geq 65$ & 0.613 & 0.518 & 0.724 & 0.839 & 0.697 & 1.011 \\
\hline \multirow{3}{*}{ DL3 } & $0-44$ & 0.760 & 0.626 & 0.921 & 0.802 & 0.656 & 0.980 \\
\hline & $45-64$ & 0.827 & 0.744 & 0.918 & 0.836 & 0.748 & 0.935 \\
\hline & $\geq 65$ & 0.648 & 0.593 & 0.708 & 0.745 & 0.674 & 0.823 \\
\hline \multirow{3}{*}{ DL4 } & $0-44$ & 0.976 & 0.695 & 1.370 & 0.801 & 0.559 & 1.141 \\
\hline & $45-64$ & 1.048 & 0.873 & 1.258 & 0.914 & 0.746 & 1.121 \\
\hline & $\geq 65$ & 0.761 & 0.650 & 0.890 & 0.686 & 0.571 & 0.823 \\
\hline \multirow{3}{*}{ DL5 } & $0-44$ & 0.753 & 0.493 & 1.142 & 1.223 & 0.799 & 1.884 \\
\hline & $45-64$ & 0.695 & 0.554 & 0.871 & 0.963 & 0.752 & 1.234 \\
\hline & $\geq 65$ & 0.673 & 0.554 & 0.816 & 0.681 & 0.555 & 0.835 \\
\hline
\end{tabular}

Note: ${ }^{a}$ DL: Deprivation level for the census tract of residence based on the deprivation index (DI). DL1: DI $<\mathrm{P}_{10}$; DL2: $\mathrm{P}_{10} \leq \mathrm{DI}<\mathrm{P}_{25} ;$ DL3: $\mathrm{P}_{25} \leq \mathrm{DI}<\mathrm{P}_{75} ;$ DL4: $\mathrm{P}_{75} \leq \mathrm{DI}<\mathrm{P}_{90} ; \mathrm{DL} 5: \mathrm{DI} \geq \mathrm{P}_{90} . \mathrm{P}_{\mathrm{q}}=$ Percentile $\mathrm{q}$.

\section{Discussion}

\subsection{Summary of Findings: Inequalities and Evolution of Death Risk}

This study has shown that the inequalities between areas of greater and lesser deprivation in both all-cause mortality and amenable mortality persist along the two study periods in the three cities, and that these inequalities appear with greater risk of death in the areas of greatest deprivation, although they present nuances depending on whether it is all-cause or amenable mortality, level of deprivation, 
age group, sex, or period. It has been found that, in general, the risks of death from all causes and amenable mortality have decreased significantly from one period to the other, although not in all the groups studied.

\subsection{Inequalities}

\subsubsection{Overall Mortality}

Inequalities in all-cause mortality among levels of deprivation have not disappeared. In some cases, although inequalities remain, the RRs have decreased for both men and women, showing in most cases a clear gradient between the most impoverished and the most favoured levels. However, in some age groups, such as men 65 and over and women $0-44$, inequalities have increased. In the case of younger men (0-44 and 45-64), inequalities tend to decrease. This result could indicate that men of working age are the recipients of pro-cyclical impacts on health. The reasons may be related to the reduction of work stress due to increased unemployment [32,33], in the specific Valencian case, due to the bursting of the housing bubble or a decrease in tobacco consumption [34], as well as the general decrease in pollution from industrial activity [35]. In other words, with the economic contraction, an overall reduction in mortality risks can be observed in men of working age. This process might have developed, to a greater extent, among the most deprived sectors, highly affected by unemployment. The analysis on the effects of pro-cyclical and counter-cyclical mechanisms proposed by Catalano et al. [33] is appropriate here.

In the case of men over 65, inequalities appear in the second period, while in the first period they were non-existent. This could be due to the fact that the economic crisis deteriorated the socioeconomic conditions of the census sections that already had high levels in all the deprivation indicators, in all three cities. This could have directly affected the age cohorts who had not yet retired, men in the later years of the working age-a situation aggravated by the feeling of not being able to fulfil the traditional provider role. This sector of men was most affected by the crisis, with deficiencies in unemployment benefits and in which the effects of this appear in the short but also in the long term, or even with permanent consequences of increased mortality, as found by Bender et al. in Greece [36].

In the case of women, inequalities persist, although not in all age groups. In women aged 65 and over, there are no inequalities in general mortality in either of the two periods, whereas in the youngest (0-44) these inequalities increase. In older women, this could be due, in part, to the fact that in the life cycle of women they achieve economic stability and establish social and family capital as they age. Furthermore, although they do not have social capital around them, both the legislative body and the institutions offer them different forms of protection. However, in the case of younger women (0-44), inequalities not only persist but tend to increase, particularly in the most disadvantaged groups. This may be due to the fact that women of this age are one of the most vulnerable sectors in times of crisis as they suffer more severely (they or their families, on whom they depend in the case of being minors or not being economically independent), due to unemployment, job insecurity, and various aspects of the so-called feminization of poverty or the intersection between poverty and gender [37]. During childbearing age, childcare can distance them from full inclusion in the labour market or the training necessary for reincorporation when the children have grown up. In the case of single-parent households, they can also bear the double burden of work and the care of children alone. This period, which can last up to two decades, depending on the number of children and the spacing between births, constitutes in itself an element of exclusion for all women, even those of the least deprived levels. In this sense, the risks of death may be related to the mechanisms of stress and frustration-aggression, and although this is shared by women of all classes, it could more sharply affect women from the most disadvantaged DLs. 


\subsubsection{Amenable Mortality}

In general terms, the existence of inequalities by age group, sex, and level of deprivation can be seen. In young men ( $0-44$ years), inequality, practically non-existent in the first period, appears in the second, although it does not reach statistical significance. Regarding the men of intermediate age (45-64) in the first period, a clear gradient of inequality in mortality is perceived, which decreases in the second period. At these ages, paradoxically, unemployment can increase healthy habits (consume less tobacco, alcohol, stress reduction, and sports) and reduce deaths from some amenable causes, such as cardiovascular disease. In the case of the elderly $(\geq 65)$, an increase in the inequalities towards old age can be perceived from the first to the second period. The combination of the factors mentioned above can influence this age.

In the case of women, inequalities in amenable mortality persist over time. Furthermore, some significant increases in RRs can be seen, i.e., regarding younger women (0-44) in DL5 and women aged 45-64 years in DL4 and DL5. This is consistent with what has been said previously in relation to the all-cause mortality over the life cycle of women. In older women $(\geq 65)$, inequalities persist with similar gradients in the two periods. This may be because women of these ages do not see their personal economic situation directly affected by the economic downturn as their pensions are not affected, as described above. On the other hand, an increase in the malignant neoplasm of the colon and rectum, as well as malignant neoplasm of cervix uteri is also perceived (see Table A5 of Appendix A). In this combination of simultaneous or successive pro-cyclical and counter-cyclical trends, short or long term, many of the mechanisms of stress, frustration-aggression, or effect budgeting described by Catalano et al. [33] might be at work.

In summary, the patterns of socioeconomic inequality in amenable mortality show some remarkable differences from those of general mortality. In women, the most notable difference occurs in the group over 65 years of age, for which the inequalities in amenable mortality remain over the two periods, whereas inequalities in general mortality are not observed in any of the periods. In the rest of the age groups, amenable mortality is similar to the overall mortality, with inequalities in both periods. In the case of men aged 0-44 years, amenable mortality presents inequalities in the second period that did not exist in the first one, while in overall mortality the inequalities remained over the two periods, although with a slight decrease. In the 45-64-year-old group, inequalities were observed in both amenable and general mortality. Finally, in those over 65 years of age, while inequalities are observed in overall mortality in the second period, the inequalities in amenable mortality were similar in both periods.

\subsection{Evolution of the Risk of Death}

Although both all-cause and amenable mortality have decreased, amenable mortality shows a more pronounced decreasing trend. This pattern had already been described in a similar way in other studies in Europe $[23,38,39]$. In the Spanish case, this might suggest that the decrease could be due to preventive measures in risk factors and advances in treatments and health technology [6], as well as the entry into force of law 42/2010 on sanitary measures against smoking that regulates the sale, supply, consumption, and advertising of tobacco [34,40].

This decline in all-cause and amenable mortality in times of crisis also seems to corroborate pro-cyclical theories of health. Although this may be so in macro-economic terms, the study of inequalities taking into account both social structure and territory allows us to identify, as in the previous paragraphs, the population groups in which the pro-cyclical decrease in all-cause or amenable mortality is not as pronounced. Furthermore, this is even for the groups in which mortality would have risen, although not significantly, in a counter-cyclical manner, i.e., men older than 65 years, women older than 45 years in the most deprived levels, or women older than 45 years in the level of least deprivation, for all causes; and middle-aged men in low deprivation and high deprivation, and young women in greater deprivation for amenable mortality. 
In general terms, as some authors argue, infra-housing, mental disorders, drug addiction, waiting lists, energy poverty, or evictions increase the risks of death [41] and must be analysed at their simultaneous intersection with health [42]. All these processes, present in the cities studied, also validate the counter-cyclical theory. For these reasons, it is important to include inequality in the analysis, and to take into account both pro-cyclical and counter-cyclical trends [11], so that the macro-figure does not hide the reality of the sectors that suffer from the countercyclical trend.

\subsection{Impact of the Crisis and Hypotheses}

Despite the general decrease in amenable mortality, socioeconomic inequalities have remained along the two research periods. This study has been carried out in urban areas of the same region, with common health policy and management, and where access to healthcare was universal during the first period. The start of the crisis meant the widespread application of cuts in healthcare investment, outsourcing of services, exclusion of social sectors from public healthcare, or increased difficulties in accessing it [43].

In this context, the endurance of inequality along the two periods could be due to complex reasons. On the one hand, the impact of health cuts could have affected, to a greater extent, the most disadvantaged population groups, preventing a possible reduction of inequalities. On the other, the results obtained are consistent with other studies carried out in Spain. In them, an effect of the socioeconomic level on mortality was observed independent from that of health care, based on the differences in access to and quality of health care, as previously suggested [6], or the lower participation by the most disadvantaged population in early detection programs (screening programs) of some diseases, such as breast cancer or colon cancer [44,45].

In addition, it should be borne in mind that the prevalence, incidence, and natural course of some diseases could have an effect on amenable mortality and differ between socioeconomic levels, as their risk factors also differ. On the other hand, survival after treatment could be affected by characteristics of individuals related to their socioeconomic level (social support, resources at home, additional medical insurance, etc.), although these variables have not been considered in this study. In any case, amenable mortality proves to be a useful indicator of the degree of efficiency of health systems, also in times of crisis. Failure to reduce or increase amenable mortality is generally accepted as a deterioration of healthcare.

\subsection{Methodological Strengths and Limitations}

This research has the usual limitations of ecological studies. Thus, it is not possible to infer a causal association. The relationship obtained between the DL and the risks of death when using the CTs may not be applicable at the individual level (i.e., ecological fallacy), reflecting both the effect of the individual socioeconomic level and the contextual effect of the area of residence.

The data analysis has been carried out jointly for the three cities. This was mainly due to reasons of statistical power. However, no important differences have been observed among the three cities regarding socioeconomic indicators (Table A2 of Appendix A). In addition, the interactions between the city and the rest of the effects on mortality, such as DL, period, and age, was not significant. Therefore, a differential effect for each city cannot be stated.

Georeferencing often entails difficulties in this kind of research. In our study, the percentage of non-georeferenced deaths is $1.3 \%$, lower than usual, and should have little effect on the results.

The list of amenable causes has been chosen for its potential for comparison with previous studies and also because other lists, even more recent ones, such as that of the AMIEHS project [46], disregards some causes and might not be appropriate for periods such as 2000-2015. The chosen list includes a wide number of amenable causes, sensitive to the effects of austerity and cutbacks in healthcare since the start of the economic crisis in Spain [22].

The inclusion of $50 \%$ of deaths from ischemic heart disease could have modified the estimated RRs among the DLs and between periods, as it is a high-frequency cause. To verify this possibility, 
such RRs were estimated, excluding deaths from this cause. As can be seen in Tables A8 and A9 of Appendix A, the RRs were hardly modified.

\section{Conclusions}

This study confirms that inequalities persisted during the two study periods, although they have not increased in general terms, except in some sectors, such as young women for amenable mortality. The patterns of inequality evolution showed some differences in amenable mortality and overall mortality in some groups according to sex and age. Thus, while for women of 65 years of age and over inequalities in amenable mortality remained over the two periods, inequalities in overall mortality were not observed in any period. In men, in the group aged 0-44 years, inequalities in amenable mortality were observed in the second period, while in the group aged 65 and over, amenable mortality presented similar inequalities in both periods, while general mortality only in the second period.

At the same time, it has also been found that the evolution of death risks from before the onset of the crisis to the period after the onset presented, overall, a general pro-cyclical trend. However, it has been possible to identify population subgroups by age, sex, and level of deprivation in which the trend, on the contrary, would be counter-cyclical (men older than 65 years, women older than 45 years in the most deprived levels, or women older than 45 years in the level of least deprivation, for all causes; and middle-aged men in low deprivation and high deprivation, as well as young women in greater deprivation for amenable mortality).

The use of the deprivation index has made it possible to identify specific geographic areas with vulnerable populations in all three cities and, at the same time, to identify the change in the level of deprivation (ascending or descending) of the geographical areas throughout the two periods. It is precisely in these areas with the greatest deprivation that more studies that deepen the knowledge of the causes of health inequalities, and those that could indicate the interventions aimed at reducing these inequalities, are needed.

Author Contributions: A.N., P.P.-Z., J.M. and P.C. participated in the research design; A.N., A.O.-A. and C.V.-H. contributed to the acquisition and organization of databases; A.N. conducted the analysis; C.V.-H. devised the deprivation index; P.P.-Z., A.O.-A., P.C. and J.M. analysed the data; P.P.-Z., J.M.C., and A.N. wrote the original draft; A.N. and J.M.C. supervised this work and critically reviewed the content; J.M.C., P.P.-Z. and A.N. reviewed and edited the final manuscript; A.N. managed the funding acquisition. All authors have read and agreed to the published version of the manuscript.

Funding: This research was partially funded by two research projects, “Cambios socioeconómicos y evolución de las desigualdades en mortalidad en áreas pequeñas de grandes ciudades en la Comunitat Valenciana" (PI16/00670) and "Desigualdades socioeconómicas y medioambientales en la distribución geográfica de la mortalidad en grandes ciudades de España (1996-2015): MEDEA3" (PI16/01004), funded by the Instituto de Salud Carlos III (co-funded by the European Regional Development Fund).

Acknowledgments: This article is part of Adriana Oliva Arocas' thesis at the Health Sciences Doctoral Programme at the University of Alicante.

Conflicts of Interest: The authors declare no conflict of interest. 


\section{Appendix A}

Table A1. International Classification of Diseases Codes, 10th revision (ICD-10), and the age ranges for the amenable causes.

\begin{tabular}{|c|c|c|c|}
\hline & Amenable Causes & ICD-10 & Age \\
\hline 1 & Intestinal infections & A00-09 & $0-14$ \\
\hline 2 & Tuberculosis & A15-A19, B90 & $0-74$ \\
\hline 3 & $\begin{array}{l}\text { Other infections (diphtheria, tetanus, } \\
\text { poliomyelitis) }\end{array}$ & $\mathrm{A} 36, \mathrm{~A} 35, \mathrm{~A} 80$ & $0-74$ \\
\hline 4 & Whooping cough & A37 & $0-14$ \\
\hline 5 & Septicaemia & A40-A41 & $0-74$ \\
\hline 6 & Measles & B05 & $1-14$ \\
\hline 7 & Malignant neoplasm of colon and rectum & $\mathrm{C} 18-\mathrm{C} 21$ & $0-74$ \\
\hline 8 & Malignant neoplasm of skin & $\mathrm{C} 44$ & $0-74$ \\
\hline 9 & Malignant neoplasm of breast & C50 & $0-74$ \\
\hline 10 & Malignant neoplasm of cervix uteri & C53 & $0-74$ \\
\hline 11 & $\begin{array}{c}\text { Malignant neoplasm of cervix uteri and } \\
\text { body of uterus }\end{array}$ & C54-C55 & $0-44$ \\
\hline 12 & Malignant neoplasm of testis & C62 & $0-74$ \\
\hline 13 & Hodgkin's disease & $\mathrm{C} 81$ & $0-74$ \\
\hline 14 & Leukaemia & C91-C95 & $0-44$ \\
\hline 15 & Diseases of the thyroid & E00-E07 & $0-74$ \\
\hline 16 & Diabetes mellitus & E10-E14 & $0-49$ \\
\hline 17 & Epilepsy & G40-G41 & $0-74$ \\
\hline 18 & Chronic rheumatic heart disease & I05-I09 & $0-74$ \\
\hline 19 & Hypertensive disease & I10-I13, I15 & $0-74$ \\
\hline 20 & Ischaemic heart disease ( $50 \%$ of deaths) & I20-I25 & $0-74$ \\
\hline 21 & Cerebrovascular disease & I60-I69 & $0-74$ \\
\hline 22 & $\begin{array}{l}\text { All respiratory diseases (excluding } \\
\text { pneumonia and influenza) }\end{array}$ & J00-J09, J20-J99 & $1-14$ \\
\hline 23 & Influenza & J10-J11 & $0-74$ \\
\hline 24 & Pneumonia & $\mathrm{J} 12-\mathrm{J} 18$ & $0-74$ \\
\hline 25 & Peptic ulcer & K25-K27 & $0-74$ \\
\hline 26 & Appendicitis & K35-K38 & $0-74$ \\
\hline 27 & Abdominal hernia & K40-K46 & $0-74$ \\
\hline 28 & Cholelithiasis and cholecystitis & K80-K81 & $0-74$ \\
\hline 29 & Nephritis and nephrosis & N00-N07,N17-N19,N25-N27 & $0-74$ \\
\hline 30 & Benign prostatic hyperplasia & N40 & $0-74$ \\
\hline 31 & Maternal death & O00-O99 & All \\
\hline 32 & Congenital cardiovascular anomalies & Q20-Q28 & $0-74$ \\
\hline 33 & Perinatal deaths, all causes & P00-P96, A33, A34 & All \\
\hline 34 & $\begin{array}{l}\text { Misadventures to patients during surgical } \\
\text { and medical care }\end{array}$ & Y60-Y69, Y83-Y84 & All \\
\hline
\end{tabular}


Table A2. Average values of the socioeconomic indicators by city, period, and percentile-based classification of the deprivation index.

\begin{tabular}{|c|c|c|c|c|c|c|c|c|c|c|c|c|c|}
\hline \multirow{3}{*}{$\begin{array}{l}\text { Socioeconomic } \\
\text { Indicator }\end{array}$} & \multirow{3}{*}{$\begin{array}{l}\text { Deprivation } \\
\text { Level (DL) }^{\text {a }}\end{array}$} & \multicolumn{4}{|c|}{ Valencia } & \multicolumn{4}{|c|}{ Alicante } & \multicolumn{4}{|c|}{ Castellón } \\
\hline & & \multicolumn{2}{|c|}{$\begin{array}{c}2000-2007 \\
\text { (2001 Census) }\end{array}$} & \multicolumn{2}{|c|}{$\begin{array}{c}2008-2015 \\
\text { (2011 Census) }\end{array}$} & \multicolumn{2}{|c|}{$\begin{array}{c}2000-2007 \\
\text { (2001 Census) }\end{array}$} & \multicolumn{2}{|c|}{$\begin{array}{c}2008-2015 \\
\text { (2011 Census) }\end{array}$} & \multicolumn{2}{|c|}{$\begin{array}{c}2000-2007 \\
\text { (2001 Census) }\end{array}$} & \multicolumn{2}{|c|}{$\begin{array}{c}2008-2015 \\
\text { (2011 Census) }\end{array}$} \\
\hline & & Mean & $\begin{array}{l}\text { Std. } \\
\text { Dev. }\end{array}$ & Mean & $\begin{array}{l}\text { Std. } \\
\text { Dev. }\end{array}$ & Mean & $\begin{array}{l}\text { Std. } \\
\text { Dev. }\end{array}$ & Mean & $\begin{array}{l}\text { Std. } \\
\text { Dev. }\end{array}$ & Mean & $\begin{array}{l}\text { Std. } \\
\text { Dev. }\end{array}$ & Mean & $\begin{array}{l}\text { Std. } \\
\text { Dev. }\end{array}$ \\
\hline \multirow{6}{*}{$\begin{array}{l}\text { People aged } 16 \\
\text { or over who } \\
\text { have a manual } \\
\text { job }\end{array}$} & DL1 & 0.177 & 0.034 & 0.142 & 0.028 & 0.230 & 0.044 & 0.174 & 0.045 & 0.313 & 0.034 & 0.276 & 0.015 \\
\hline & DL2 & 0.276 & 0.045 & 0.231 & 0.040 & 0.332 & 0.052 & 0.298 & 0.060 & 0.420 & 0.044 & 0.349 & 0.037 \\
\hline & DL3 & 0.479 & 0.087 & 0.444 & 0.090 & 0.546 & 0.087 & 0.527 & 0.101 & 0.575 & 0.085 & 0.529 & 0.087 \\
\hline & DL4 & 0.647 & 0.045 & 0.605 & 0.055 & 0.686 & 0.061 & 0.697 & 0.066 & 0.751 & 0.033 & 0.685 & 0.029 \\
\hline & DL5 & 0.710 & 0.055 & 0.696 & 0.063 & 0.797 & 0.043 & 0.786 & 0.075 & 0.798 & 0.048 & 0.726 & 0.051 \\
\hline & Total & 0.467 & 0.172 & 0.432 & 0.177 & 0.529 & 0.174 & 0.509 & 0.194 & 0.575 & 0.153 & 0.521 & 0.149 \\
\hline \multirow{6}{*}{$\begin{array}{l}\text { People aged } \\
\text { over } 16 \text { years } \\
\text { out of work }\end{array}$} & DL1 & 0.099 & 0.019 & 0.204 & 0.034 & 0.096 & 0.019 & 0.220 & 0.033 & 0.086 & 0.012 & 0.283 & 0.033 \\
\hline & DL2 & 0.122 & 0.024 & 0.233 & 0.031 & 0.115 & 0.024 & 0.262 & 0.035 & 0.088 & 0.017 & 0.308 & 0.034 \\
\hline & DL3 & 0.146 & 0.027 & 0.287 & 0.042 & 0.138 & 0.035 & 0.345 & 0.051 & 0.095 & 0.015 & 0.338 & 0.050 \\
\hline & DL4 & 0.162 & 0.030 & 0.333 & 0.042 & 0.155 & 0.044 & 0.399 & 0.038 & 0.095 & 0.014 & 0.405 & 0.051 \\
\hline & DL5 & 0.200 & 0.046 & 0.388 & 0.053 & 0.197 & 0.043 & 0.502 & 0.082 & 0.112 & 0.010 & 0.369 & 0.017 \\
\hline & Total & 0.145 & 0.038 & 0.287 & 0.064 & 0.138 & 0.042 & 0.343 & 0.088 & 0.095 & 0.016 & 0.342 & 0.056 \\
\hline \multirow{6}{*}{$\begin{array}{l}\text { People aged } 16 \\
\text { or over in } \\
\text { temporary } \\
\text { employment }\end{array}$} & DL1 & 0.160 & 0.023 & 0.111 & 0.030 & 0.182 & 0.030 & 0.125 & 0.016 & 0.171 & 0.031 & 0.137 & 0.022 \\
\hline & DL2 & 0.191 & 0.028 & 0.131 & 0.037 & 0.213 & 0.029 & 0.153 & 0.024 & 0.212 & 0.021 & 0.156 & 0.013 \\
\hline & DL3 & 0.238 & 0.036 & 0.167 & 0.045 & 0.280 & 0.046 & 0.199 & 0.030 & 0.232 & 0.033 & 0.182 & 0.034 \\
\hline & DL4 & 0.275 & 0.036 & 0.211 & 0.060 & 0.352 & 0.046 & 0.243 & 0.039 & 0.242 & 0.043 & 0.203 & 0.020 \\
\hline & DL5 & 0.326 & 0.042 & 0.239 & 0.063 & 0.414 & 0.086 & 0.302 & 0.048 & 0.286 & 0.047 & 0.189 & 0.033 \\
\hline & Total & 0.238 & 0.056 & 0.170 & 0.060 & 0.284 & 0.080 & 0.201 & 0.056 & 0.230 & 0.042 & 0.178 & 0.033 \\
\hline \multirow{6}{*}{$\begin{array}{c}\text { People aged } \\
\text { over } 16 \text { years } \\
\text { with low } \\
\text { education level }\end{array}$} & DL1 & 0.112 & 0.033 & 0.076 & 0.020 & 0.126 & 0.030 & 0.088 & 0.029 & 0.204 & 0.036 & 0.126 & 0.012 \\
\hline & DL2 & 0.187 & 0.034 & 0.120 & 0.023 & 0.213 & 0.042 & 0.128 & 0.037 & 0.253 & 0.024 & 0.148 & 0.012 \\
\hline & DL3 & 0.301 & 0.060 & 0.198 & 0.045 & 0.332 & 0.058 & 0.222 & 0.042 & 0.354 & 0.054 & 0.207 & 0.045 \\
\hline & DL4 & 0.417 & 0.040 & 0.280 & 0.036 & 0.419 & 0.043 & 0.293 & 0.045 & 0.496 & 0.056 & 0.279 & 0.028 \\
\hline & DL5 & 0.517 & 0.051 & 0.353 & 0.047 & 0.556 & 0.073 & 0.410 & 0.099 & 0.576 & 0.051 & 0.363 & 0.046 \\
\hline & Total & 0.304 & 0.121 & 0.202 & 0.086 & 0.329 & 0.123 & 0.223 & 0.098 & 0.366 & 0.115 & 0.215 & 0.073 \\
\hline \multirow{6}{*}{$\begin{array}{c}\text { People aged } 16 \\
\text { to } 29 \text { years with } \\
\text { low education } \\
\text { level }\end{array}$} & DL1 & 0.030 & 0.014 & 0.018 & 0.008 & 0.049 & 0.023 & 0.019 & 0.008 & 0.070 & 0.025 & 0.061 & 0.029 \\
\hline & DL2 & 0.051 & 0.017 & 0.033 & 0.021 & 0.073 & 0.024 & 0.033 & 0.018 & 0.100 & 0.028 & 0.051 & 0.014 \\
\hline & DL3 & 0.092 & 0.025 & 0.056 & 0.031 & 0.114 & 0.040 & 0.083 & 0.035 & 0.136 & 0.028 & 0.088 & 0.030 \\
\hline & DL4 & 0.139 & 0.028 & 0.103 & 0.049 & 0.174 & 0.037 & 0.128 & 0.046 & 0.226 & 0.052 & 0.138 & 0.030 \\
\hline & DL5 & 0.226 & 0.058 & 0.197 & 0.073 & 0.287 & 0.105 & 0.303 & 0.161 & 0.323 & 0.046 & 0.188 & 0.013 \\
\hline & Total & 0.100 & 0.059 & 0.070 & 0.061 & 0.127 & 0.078 & 0.097 & 0.094 & 0.155 & 0.075 & 0.096 & 0.047 \\
\hline
\end{tabular}

Note: a DL: Deprivation level of the census track of residence based on the deprivation index (DI). DL1: DI $<\mathrm{P}_{10}$; DL2: $\mathrm{P}_{10} \leq \mathrm{DI}<\mathrm{P}_{25}$; DL3: $\mathrm{P}_{25} \leq \mathrm{DI}<\mathrm{P}_{75}$; DL4: $\mathrm{P}_{75} \leq \mathrm{DI}<\mathrm{P}_{90}$; DL5: DI $\geq$

$\mathrm{P}_{90} ; \mathrm{P}_{\mathrm{q}}=$ Percentile $\mathrm{q}$. 
Table A3. Average annual population for the three cities by period, age group, sex, and percentile-based classification of the deprivation index.

\begin{tabular}{|c|c|c|c|c|c|c|c|}
\hline \multirow{2}{*}{ Period } & \multirow{2}{*}{$\begin{array}{l}\text { Deprivation } \\
\text { Level (DL) }^{a}\end{array}$} & \multicolumn{2}{|c|}{$0-44$} & \multicolumn{2}{|c|}{$45-64$} & \multicolumn{2}{|c|}{$\geq 65$} \\
\hline & & Men & Women & Men & Women & Men & Women \\
\hline \multirow{6}{*}{ 2000-2007 } & DL1 & 27,649 & 28,172 & 11,642 & 14,050 & 6802 & 11,100 \\
\hline & DL2 & 61,455 & 61,018 & 23,269 & 26,272 & 12,625 & 19,926 \\
\hline & DL3 & 198,787 & 193,125 & 71,408 & 79,503 & 41,207 & 62,468 \\
\hline & DL4 & 55,670 & 51,990 & 20,026 & 21,407 & 12,805 & 18,065 \\
\hline & DL5 & 34,655 & 30,895 & 11,070 & 11,989 & 8705 & 12,994 \\
\hline & Total & 378,213 & 365,200 & 137,416 & 153,219 & 82,144 & 124,552 \\
\hline \multirow{6}{*}{ 2008-2015 } & DL1 & 23,122 & 23,128 & 11,377 & 13,725 & 7600 & 12,044 \\
\hline & DL2 & 69,293 & 68,923 & 29,524 & 33,207 & 15,390 & 22,695 \\
\hline & DL3 & 198,369 & 191,465 & 85,647 & 94,619 & 47,885 & 70,375 \\
\hline & DL4 & 52,128 & 48,464 & 21,396 & 22,664 & 13,292 & 19,839 \\
\hline & DL5 & 35,897 & 31,253 & 12,886 & 12,951 & 8486 & 12,493 \\
\hline & Total & 378,808 & 363,229 & 160,829 & 177,164 & 92,650 & 137,443 \\
\hline
\end{tabular}

Note: ${ }^{a}$ DL: Deprivation level of the census track of residence based on the deprivation index (DI). DL1: DI $<\mathrm{P}_{10}$; DL2: $\mathrm{P}_{10} \leq \mathrm{DI}<\mathrm{P}_{25}$; DL3: $\mathrm{P}_{25} \leq$ DI $<\mathrm{P}_{75} ;$ DL4: $\mathrm{P}_{75} \leq \mathrm{DI}<\mathrm{P}_{90}$; DL5: DI $\geq \mathrm{P}_{90} . \mathrm{P}_{\mathrm{q}}=$ Percentile $\mathrm{q}$. 
Table A4. Frequencies and percentages ${ }^{a}$ of death for various amenable causes, by sex, period, and level of deprivation (DL) ${ }^{b}$. All cities together, $2000-2015$.

\begin{tabular}{|c|c|c|c|c|c|c|c|c|c|c|c|c|}
\hline \multirow{3}{*}{ Men } & \multicolumn{12}{|c|}{ Deprivation Level (DL) $^{\mathrm{b}}$} \\
\hline & \multicolumn{2}{|c|}{ DL1 } & \multicolumn{2}{|c|}{ DL2 } & \multicolumn{2}{|c|}{ DL3 } & \multicolumn{2}{|c|}{ DL4 } & \multicolumn{2}{|c|}{ DL5 } & \multicolumn{2}{|c|}{ Total } \\
\hline & 2000-2007 & 2008-2015 & 2000-2007 & 2008-2015 & 2000-2007 & 2008-2015 & 2000-2007 & 2008-2015 & 2000-2007 & 2008-2015 & 2000-2007 & 2008-2015 \\
\hline \multirow{2}{*}{ Septicaemia } & 12 & 3 & 20 & 12 & 74 & 45 & 20 & 16 & 25 & 6 & 151 & 82 \\
\hline & $4.0 \%$ & $1.3 \%$ & $3.2 \%$ & $2.6 \%$ & $3.5 \%$ & $2.6 \%$ & $3.1 \%$ & $2.7 \%$ & $5.2 \%$ & $1.7 \%$ & $3.7 \%$ & $2.4 \%$ \\
\hline \multirow{2}{*}{$\begin{array}{l}\text { Malignant neoplasm of colon and } \\
\text { rectum }\end{array}$} & 73 & 70 & 135 & 108 & 416 & 448 & 126 & 144 & 104 & 85 & 854 & 855 \\
\hline & $24.6 \%$ & $30.3 \%$ & $21.8 \%$ & $23.0 \%$ & $19.9 \%$ & $25.8 \%$ & $19.7 \%$ & $24.5 \%$ & $21.8 \%$ & $24.6 \%$ & $20.7 \%$ & $25.4 \%$ \\
\hline \multirow{2}{*}{ Malignant neoplasm of breast } & 2 & 0 & 2 & 0 & 1 & 5 & 0 & 2 & 0 & 0 & 5 & 7 \\
\hline & $0.7 \%$ & $0.0 \%$ & $0.3 \%$ & $0.0 \%$ & $0.0 \%$ & $0.3 \%$ & $0.0 \%$ & $0.3 \%$ & $0.0 \%$ & $0.0 \%$ & $0.1 \%$ & $0.2 \%$ \\
\hline \multirow{2}{*}{ Chronic rheumatic heart disease } & 0 & 2 & 9 & 8 & 31 & 32 & 10 & 5 & 8 & 2 & 58 & 49 \\
\hline & $0.0 \%$ & $0.9 \%$ & $1.5 \%$ & $1.7 \%$ & $1.5 \%$ & $1.8 \%$ & $1.6 \%$ & $0.9 \%$ & $1.7 \%$ & $0.6 \%$ & $1.4 \%$ & $1.5 \%$ \\
\hline \multirow{2}{*}{ Hypertensive disease } & 9 & 6 & 11 & 25 & 59 & 74 & 19 & 26 & 8 & 17 & 106 & 148 \\
\hline & $3.0 \%$ & $2.6 \%$ & $1.8 \%$ & $5.3 \%$ & $2.8 \%$ & $4.3 \%$ & $3.0 \%$ & $4.4 \%$ & $1.7 \%$ & $4.9 \%$ & $2.6 \%$ & $4.4 \%$ \\
\hline \multirow{2}{*}{$\begin{array}{l}\text { Ischaemic heart disease ( } 50 \% \text { of } \\
\text { deaths) }\end{array}$} & 86 & 56 & 175 & 128 & 606 & 446 & 180 & 143 & 117 & 91 & 1164 & 864 \\
\hline & $29.0 \%$ & $24.2 \%$ & $28.2 \%$ & $27.3 \%$ & $29.1 \%$ & $25.6 \%$ & $28.1 \%$ & $24.4 \%$ & $24.5 \%$ & $26.4 \%$ & $28.2 \%$ & $25.6 \%$ \\
\hline \multirow{2}{*}{ Cerebrovascular disease } & 63 & 47 & 128 & 89 & 437 & 314 & 127 & 105 & 105 & 65 & 860 & 620 \\
\hline & $21.2 \%$ & $20.3 \%$ & $20.6 \%$ & $19.0 \%$ & $20.9 \%$ & $18.1 \%$ & $19.8 \%$ & $17.9 \%$ & $22.0 \%$ & $18.8 \%$ & $20.9 \%$ & $18.4 \%$ \\
\hline \multirow{2}{*}{$\begin{array}{l}\text { All respiratory diseases (excl. } \\
\text { pneumonia and influenza) }\end{array}$} & 13 & 21 & 47 & 25 & 157 & 126 & 73 & 48 & 41 & 31 & 331 & 251 \\
\hline & $4.4 \%$ & $9.1 \%$ & $7.6 \%$ & $5.3 \%$ & $7.5 \%$ & $7.2 \%$ & $11.4 \%$ & $8.2 \%$ & $8.6 \%$ & $9.0 \%$ & $8.0 \%$ & $7.4 \%$ \\
\hline \multirow{2}{*}{ Pneumonia } & 10 & 5 & 16 & 21 & 90 & 62 & 28 & 25 & 18 & 14 & 162 & 127 \\
\hline & $3.4 \%$ & $2.2 \%$ & $2.6 \%$ & $4.5 \%$ & $4.3 \%$ & $3.6 \%$ & $4.4 \%$ & $4.3 \%$ & $3.8 \%$ & $4.1 \%$ & $3.9 \%$ & $3.8 \%$ \\
\hline \multirow{2}{*}{ Perinatal deaths, all causes } & 9 & 5 & 25 & 18 & 56 & 44 & 12 & 14 & 13 & 10 & 115 & 91 \\
\hline & $3.0 \%$ & $2.2 \%$ & $4.0 \%$ & $3.8 \%$ & $2.7 \%$ & $2.5 \%$ & $1.9 \%$ & $2.4 \%$ & $2.7 \%$ & $2.9 \%$ & $2.8 \%$ & $2.7 \%$ \\
\hline \multirow{2}{*}{$\begin{array}{l}\text { Misadventures to patients during } \\
\text { surgical and medical care }\end{array}$} & 0 & 2 & 2 & 5 & 1 & 19 & 1 & 6 & 1 & 2 & 5 & 34 \\
\hline & $0.0 \%$ & $0.9 \%$ & $0.3 \%$ & $1.1 \%$ & $0.0 \%$ & $1.1 \%$ & $0.2 \%$ & $1.0 \%$ & $0.2 \%$ & $0.6 \%$ & $0.1 \%$ & $1.0 \%$ \\
\hline \multirow{2}{*}{ Other amenable causes } & 20 & 14 & 50 & 30 & 158 & 124 & 45 & 53 & 37 & 22 & 310 & 243 \\
\hline & $6.7 \%$ & $6.1 \%$ & $8.1 \%$ & $6.4 \%$ & $7.6 \%$ & $7.1 \%$ & $7.0 \%$ & $9.0 \%$ & $7.8 \%$ & $6.4 \%$ & $7.5 \%$ & $7.2 \%$ \\
\hline Total amenable & 297 & 231 & 620 & 469 & 2086 & 1739 & 641 & 587 & 477 & 345 & 4121 & 3371 \\
\hline
\end{tabular}


Table A4. Cont.

\begin{tabular}{|c|c|c|c|c|c|c|c|c|c|c|c|c|}
\hline \multirow{3}{*}{ Women } & \multicolumn{12}{|c|}{ Deprivation Level (DL) $^{b}$} \\
\hline & \multicolumn{2}{|c|}{ DL1 } & \multicolumn{2}{|c|}{ DL2 } & \multicolumn{2}{|c|}{ DL3 } & \multicolumn{2}{|c|}{ DL4 } & \multicolumn{2}{|c|}{ DL5 } & \multicolumn{2}{|c|}{ Total } \\
\hline & $2000-2007$ & 2008-2015 & $2000-2007$ & 2008-2015 & $2000-2007$ & 2008-2015 & $2000-2007$ & 2008-2015 & $2000-2007$ & $2008-2015$ & $2000-2007$ & $2008-2015$ \\
\hline \multirow{2}{*}{ Septicaemia } & 7 & 6 & 8 & 6 & 36 & 29 & 10 & 7 & 13 & 10 & 74 & 58 \\
\hline & $2.8 \%$ & $3.2 \%$ & $1.6 \%$ & $1.2 \%$ & $2.2 \%$ & $2.0 \%$ & $1.9 \%$ & $1.6 \%$ & $3.3 \%$ & $3.1 \%$ & $1.9 \%$ & $2.0 \%$ \\
\hline \multirow{2}{*}{$\begin{array}{l}\text { Malignant neoplasm of colon and } \\
\text { rectum }\end{array}$} & 44 & 33 & 86 & 91 & 260 & 280 & 81 & 76 & 52 & 70 & 523 & 550 \\
\hline & $17.7 \%$ & $17.7 \%$ & $16.7 \%$ & $18.8 \%$ & $15.6 \%$ & $18.8 \%$ & $15.4 \%$ & $17.4 \%$ & $13.2 \%$ & $21.4 \%$ & $15.6 \%$ & $18.8 \%$ \\
\hline \multirow{2}{*}{ Malignant neoplasm of breast } & 86 & 64 & 173 & 173 & 431 & 419 & 138 & 119 & 90 & 57 & 918 & 832 \\
\hline & $34.5 \%$ & $34.4 \%$ & $33.5 \%$ & $35.7 \%$ & $25.8 \%$ & $28.2 \%$ & $26.2 \%$ & $27.2 \%$ & $22.9 \%$ & $17.4 \%$ & $27.4 \%$ & $28.5 \%$ \\
\hline \multirow{2}{*}{$\begin{array}{l}\text { Malignant neoplasm of cervix uteri or } \\
\text { cervix uteri and body of uterus }\end{array}$} & 15 & 11 & 34 & 40 & 128 & 162 & 38 & 48 & 34 & 33 & 249 & 294 \\
\hline & $6.0 \%$ & $5.9 \%$ & $6.6 \%$ & $8.2 \%$ & $7.7 \%$ & $10.9 \%$ & $7.2 \%$ & $11.0 \%$ & $8.7 \%$ & $10.1 \%$ & $7.4 \%$ & $10.1 \%$ \\
\hline \multirow{2}{*}{ Chronic rheumatic heart disease } & 6 & 12 & 17 & 11 & 64 & 42 & 27 & 11 & 15 & 13 & 129 & 89 \\
\hline & $2.4 \%$ & $6.5 \%$ & $3.3 \%$ & $2.3 \%$ & $3.8 \%$ & $2.8 \%$ & $5.1 \%$ & $2.5 \%$ & $3.8 \%$ & $4.0 \%$ & $3.8 \%$ & $3.0 \%$ \\
\hline \multirow{2}{*}{ Hypertensive disease } & 3 & 7 & 4 & 11 & 37 & 49 & 23 & 13 & 11 & 11 & 78 & 91 \\
\hline & $1.2 \%$ & $3.8 \%$ & $0.8 \%$ & $2.3 \%$ & $2.2 \%$ & $3.3 \%$ & $4.4 \%$ & $3.0 \%$ & $2.8 \%$ & $3.4 \%$ & $2.3 \%$ & $3.1 \%$ \\
\hline \multirow{2}{*}{$\begin{array}{l}\text { Ischaemic heart disease (50\% of } \\
\text { deaths) }\end{array}$} & 21 & 10 & 39 & 25 & 135 & 62 & 37 & 30 & 36 & 20 & 268 & 147 \\
\hline & $8.4 \%$ & $5.4 \%$ & $7.6 \%$ & $5.2 \%$ & $8.1 \%$ & $4.2 \%$ & $7.0 \%$ & $6.9 \%$ & $9.2 \%$ & $6.1 \%$ & $8.0 \%$ & $5.0 \%$ \\
\hline \multirow{2}{*}{ Cerebrovascular disease } & 41 & 23 & 86 & 53 & 309 & 200 & 96 & 63 & 74 & 58 & 606 & 397 \\
\hline & $16.5 \%$ & $12.4 \%$ & $16.7 \%$ & $10.9 \%$ & $18.5 \%$ & $13.5 \%$ & $18.2 \%$ & $14.4 \%$ & $18.8 \%$ & $17.7 \%$ & $18.1 \%$ & $13.6 \%$ \\
\hline \multirow{2}{*}{$\begin{array}{l}\text { All respiratory diseases (excl. } \\
\text { pneumonia and influenza) }\end{array}$} & 7 & 4 & 16 & 14 & 72 & 69 & 17 & 20 & 17 & 14 & 129 & 121 \\
\hline & $2.8 \%$ & $2.2 \%$ & $3.1 \%$ & $2.9 \%$ & $4.3 \%$ & $4.6 \%$ & $3.2 \%$ & $4.6 \%$ & $4.3 \%$ & $4.3 \%$ & $3.8 \%$ & $4.1 \%$ \\
\hline \multirow{2}{*}{ Pneumonia } & 4 & 6 & 12 & 11 & 45 & 34 & 17 & 7 & 18 & 8 & 96 & 66 \\
\hline & $1.6 \%$ & $3.2 \%$ & $2.3 \%$ & $2.3 \%$ & $2.7 \%$ & $2.3 \%$ & $3.2 \%$ & $1.6 \%$ & $4.6 \%$ & $2.4 \%$ & $2.9 \%$ & $2.3 \%$ \\
\hline \multirow{2}{*}{ Perinatal deaths, all causes } & 5 & 4 & 18 & 18 & 41 & 36 & 8 & 17 & 7 & 10 & 79 & 85 \\
\hline & $2.0 \%$ & $2.2 \%$ & $3.5 \%$ & $3.7 \%$ & $2.5 \%$ & $2.4 \%$ & $1.5 \%$ & $3.9 \%$ & $1.8 \%$ & $3.1 \%$ & $2.4 \%$ & $2.9 \%$ \\
\hline \multirow{2}{*}{$\begin{array}{l}\text { Misadventures to patients during } \\
\text { surgical and medical care }\end{array}$} & 1 & 0 & 0 & 8 & 3 & 17 & 1 & 6 & 0 & 2 & 5 & 33 \\
\hline & $0.4 \%$ & $0.0 \%$ & $0.0 \%$ & $1.6 \%$ & $0.2 \%$ & $1.1 \%$ & $0.2 \%$ & $1.4 \%$ & $0.0 \%$ & $0.6 \%$ & $0.1 \%$ & $1.1 \%$ \\
\hline \multirow{2}{*}{ Other amenable causes } & 9 & 6 & 23 & 24 & 107 & 87 & 34 & 20 & 24 & 21 & 199 & 158 \\
\hline & $3.6 \%$ & $3.2 \%$ & $4.5 \%$ & $4.9 \%$ & $6.4 \%$ & $5.9 \%$ & $6.5 \%$ & $4.6 \%$ & $6.1 \%$ & $6.4 \%$ & $5.9 \%$ & $5.4 \%$ \\
\hline Total amenable & 249 & 186 & 516 & 485 & 1668 & 1486 & 527 & 437 & 393 & 327 & 3353 & 2921 \\
\hline
\end{tabular}

Note: ${ }^{\text {a }}$ Percentages have been calculated in relation to the total of amenable deaths for the period and DL. ${ }^{\mathrm{b}}$ DL: Deprivation level of the census track of residence based on the deprivation index (DI). DL1: DI $<\mathrm{P}_{10}$; DL2: $\mathrm{P}_{10} \leq \mathrm{DI}<\mathrm{P}_{25}$; DL3: $\mathrm{P}_{25} \leq \mathrm{DI}<\mathrm{P}_{75} ; \mathrm{DL} 4: \mathrm{P}_{75} \leq \mathrm{DI}<\mathrm{P}_{90}$; DL5: DI $\geq \mathrm{P}_{90}$. $\mathrm{P}_{\mathrm{q}}=$ Percentile $\mathrm{q}$. 
Table A5. Frequencies and percentages of death according to the large groups of the ICD-10, by sex, level of deprivation, and period. All cities together, $2000-2015$.

\begin{tabular}{|c|c|c|c|c|c|c|c|c|c|c|c|c|c|}
\hline \multirow{3}{*}{ Men } & \multicolumn{12}{|c|}{ Deprivation Level (DL) $^{a}$} & \multirow{3}{*}{ Total } \\
\hline & \multicolumn{2}{|c|}{ DL1 } & \multicolumn{2}{|c|}{ DL2 } & \multicolumn{2}{|c|}{ DL3 } & \multicolumn{2}{|c|}{ DL4 } & \multicolumn{2}{|c|}{ DL5 } & \multicolumn{2}{|c|}{ Total } & \\
\hline & 2000-2007 & 2008-2015 & 2000-2007 & $2008-2015$ & 2000-2007 & 2008-2015 & $2000-2007$ & $2008-2015$ & 2000-2007 & $2008-2015$ & 2000-2007 & $2008-2015$ & \\
\hline \multirow{2}{*}{ I: Infectious and parasitic diseases } & 60 & 37 & 154 & 124 & 508 & 404 & 192 & 133 & 200 & 108 & 1114 & 806 & 1920 \\
\hline & $1.7 \%$ & $1.2 \%$ & $2.3 \%$ & $1.9 \%$ & $2.3 \%$ & $1.8 \%$ & $2.8 \%$ & $2.0 \%$ & $4.0 \%$ & $2.3 \%$ & $2.5 \%$ & $1.8 \%$ & $2.2 \%$ \\
\hline \multirow{2}{*}{ II: Neoplasms } & 1208 & 1036 & 2163 & 2277 & 7214 & 7812 & 2252 & 2244 & 1587 & 1577 & 14,424 & 14,946 & 29,370 \\
\hline & $34.0 \%$ & $32.5 \%$ & $32.3 \%$ & $34.0 \%$ & $32.4 \%$ & $34.6 \%$ & $32.5 \%$ & $33.2 \%$ & $31.8 \%$ & $34.0 \%$ & $32.5 \%$ & $34.1 \%$ & $33.3 \%$ \\
\hline \multirow{2}{*}{$\begin{array}{l}\text { III: Diseases of the blood, and } \\
\text { inmunity disorders }\end{array}$} & 8 & 10 & 18 & 25 & 60 & 56 & 24 & 21 & 9 & 11 & 119 & 123 & 242 \\
\hline & $0.2 \%$ & $0.3 \%$ & $0.3 \%$ & $0.4 \%$ & $0.3 \%$ & $0.2 \%$ & $0.3 \%$ & $0.3 \%$ & $0.2 \%$ & $0.2 \%$ & $0.3 \%$ & $0.3 \%$ & $0.3 \%$ \\
\hline \multirow{2}{*}{$\begin{array}{l}\text { IV: Endocrine, nutritional and } \\
\text { metabolic diseases }\end{array}$} & 82 & 68 & 154 & 150 & 492 & 518 & 174 & 181 & 123 & 119 & 1025 & 1036 & 2061 \\
\hline & $2.3 \%$ & $2.1 \%$ & $2.3 \%$ & $2.2 \%$ & $2.2 \%$ & $2.3 \%$ & $2.5 \%$ & $2.7 \%$ & $2.5 \%$ & $2.6 \%$ & $2.3 \%$ & $2.4 \%$ & $2.3 \%$ \\
\hline \multirow{2}{*}{ V: Mental and behavioural disorders } & 66 & 80 & 147 & 181 & 435 & 659 & 145 & 190 & 95 & 130 & 888 & 1240 & 2128 \\
\hline & $1.9 \%$ & $2.5 \%$ & $2.2 \%$ & $2.7 \%$ & $2.0 \%$ & $2.9 \%$ & $2.1 \%$ & $2.8 \%$ & $1.9 \%$ & $2.8 \%$ & $2.0 \%$ & $2.8 \%$ & $2.4 \%$ \\
\hline \multirow{2}{*}{$\begin{array}{l}\text { VI-VIII: Diseases of the nervous } \\
\text { system and organ senses }\end{array}$} & 123 & 161 & 195 & 367 & 718 & 1075 & 216 & 284 & 130 & 188 & 1382 & 2075 & 3457 \\
\hline & $3.5 \%$ & $5.1 \%$ & $2.9 \%$ & $5.5 \%$ & $3.2 \%$ & $4.8 \%$ & $3.1 \%$ & $4.2 \%$ & $2.6 \%$ & $4.0 \%$ & $3.1 \%$ & $4.7 \%$ & $3.9 \%$ \\
\hline \multirow{2}{*}{ IX: Diseases of the circulatory system } & 1129 & 977 & 2098 & 1901 & 6775 & 6316 & 1942 & 1869 & 1376 & 1215 & 13,320 & 12,278 & 25,598 \\
\hline & $31.8 \%$ & $30.7 \%$ & $31.4 \%$ & $28.4 \%$ & $30.5 \%$ & $28.0 \%$ & $28.0 \%$ & $27.6 \%$ & $27.6 \%$ & $26.2 \%$ & $30.0 \%$ & $28.0 \%$ & $29.0 \%$ \\
\hline \multirow{2}{*}{$X$ : Diseases of the respiratory system } & 386 & 401 & 810 & 761 & 2796 & 2675 & 940 & 842 & 685 & 627 & 5617 & 5306 & 10,923 \\
\hline & $10.9 \%$ & $12.6 \%$ & $12.1 \%$ & $11.4 \%$ & $12.6 \%$ & $11.9 \%$ & $13.6 \%$ & $12.5 \%$ & $13.7 \%$ & $13.5 \%$ & $12.6 \%$ & $12.1 \%$ & $12.4 \%$ \\
\hline \multirow{2}{*}{ XI: Diseases of the digestive system } & 161 & 148 & 280 & 309 & 1195 & 1130 & 400 & 377 & 294 & 251 & 2330 & 2215 & 4545 \\
\hline & $4.5 \%$ & $4.6 \%$ & $4.2 \%$ & $4.6 \%$ & $5.4 \%$ & $5.0 \%$ & $5.8 \%$ & $5.6 \%$ & $5.9 \%$ & $5.4 \%$ & $5.2 \%$ & $5.1 \%$ & $5.1 \%$ \\
\hline \multirow{2}{*}{$\begin{array}{l}\text { XII: Diseases of the skin and } \\
\text { subcutaneous tissue }\end{array}$} & 10 & 7 & 13 & 8 & 48 & 49 & 9 & 19 & 6 & 12 & 86 & 95 & 181 \\
\hline & $0.3 \%$ & $0.2 \%$ & $0.2 \%$ & $0.1 \%$ & $0.2 \%$ & $0.2 \%$ & $0.1 \%$ & $0.3 \%$ & $0.1 \%$ & $0.3 \%$ & $0.2 \%$ & $0.2 \%$ & $0.2 \%$ \\
\hline \multirow{2}{*}{$\begin{array}{l}\text { XIII: Diseases of the musculoskeletal } \\
\text { system and connective tissue }\end{array}$} & 12 & 15 & 30 & 34 & 71 & 90 & 30 & 32 & 18 & 21 & 161 & 192 & 353 \\
\hline & $0.3 \%$ & $0.5 \%$ & $0.4 \%$ & $0.5 \%$ & $0.3 \%$ & $0.4 \%$ & $0.4 \%$ & $0.5 \%$ & $0.4 \%$ & $0.5 \%$ & $0.4 \%$ & $0.4 \%$ & $0.4 \%$ \\
\hline \multirow{2}{*}{$\begin{array}{c}\text { XIV: Diseases of the genitourinary } \\
\text { system }\end{array}$} & 102 & 99 & 156 & 201 & 509 & 560 & 154 & 197 & 119 & 106 & 1040 & 1163 & 2203 \\
\hline & $2.9 \%$ & $3.1 \%$ & $2.3 \%$ & $3.0 \%$ & $2.3 \%$ & $2.5 \%$ & $2.2 \%$ & $2.9 \%$ & $2.4 \%$ & $2.3 \%$ & $2.3 \%$ & $2.7 \%$ & $2.5 \%$ \\
\hline \multirow{2}{*}{$\begin{array}{l}\text { XV: Pregnancy, childbirth and the } \\
\text { puerperium }\end{array}$} & 9 & 5 & 25 & 18 & 56 & 44 & 12 & 14 & 13 & 10 & 115 & 91 & 206 \\
\hline & $0.3 \%$ & $0.2 \%$ & $0.4 \%$ & $0.3 \%$ & $0.3 \%$ & $0.2 \%$ & $0.2 \%$ & $0.2 \%$ & $0.3 \%$ & $0.2 \%$ & $0.3 \%$ & $0.2 \%$ & $0.2 \%$ \\
\hline
\end{tabular}


Table A5. Cont.

\begin{tabular}{|c|c|c|c|c|c|c|c|c|c|c|c|c|c|}
\hline \multirow{3}{*}{ Men } & \multicolumn{12}{|c|}{ Deprivation Level (DL) $^{a}$} & \multirow{3}{*}{ Total } \\
\hline & \multicolumn{2}{|c|}{ DL1 } & \multicolumn{2}{|c|}{ DL2 } & \multicolumn{2}{|c|}{ DL3 } & \multicolumn{2}{|c|}{ DL4 } & \multicolumn{2}{|c|}{ DL5 } & \multicolumn{2}{|c|}{ Total } & \\
\hline & $2000-2007$ & $2008-2015$ & $2000-2007$ & $2008-2015$ & $2000-2007$ & 2008-2015 & $2000-2007$ & 2008-2015 & $2000-2007$ & $2008-2015$ & $2000-2007$ & 2008-2015 & \\
\hline \multirow{2}{*}{$\begin{array}{l}\mathrm{XVI} \text { : Certain conditions originating } \\
\text { in the perinatal period }\end{array}$} & 5 & 7 & 23 & 15 & 48 & 40 & 13 & 16 & 10 & 11 & 99 & 89 & 188 \\
\hline & $0.1 \%$ & $0.2 \%$ & $0.3 \%$ & $0.2 \%$ & $0.2 \%$ & $0.2 \%$ & $0.2 \%$ & $0.2 \%$ & $0.2 \%$ & $0.2 \%$ & $0.2 \%$ & $0.2 \%$ & $0.2 \%$ \\
\hline \multirow{2}{*}{ XVII: Congenital malformations } & 38 & 25 & 78 & 72 & 242 & 231 & 70 & 55 & 56 & 53 & 484 & 436 & 920 \\
\hline & $1.1 \%$ & $0.8 \%$ & $1.2 \%$ & $1.1 \%$ & $1.1 \%$ & $1.0 \%$ & $1.0 \%$ & $0.8 \%$ & $1.1 \%$ & $1.1 \%$ & $1.1 \%$ & $1.0 \%$ & $1.0 \%$ \\
\hline \multirow{2}{*}{$\begin{array}{l}\text { XVIII: Symptoms and signs not } \\
\text { elsewhere classified }\end{array}$} & 151 & 111 & 347 & 254 & 1073 & 893 & 364 & 287 & 273 & 206 & 2208 & 1751 & 3959 \\
\hline & $4.3 \%$ & $3.5 \%$ & $5.2 \%$ & $3.8 \%$ & $4.8 \%$ & $4.0 \%$ & $5.2 \%$ & $4.2 \%$ & $5.5 \%$ & $4.4 \%$ & $5.0 \%$ & $4.0 \%$ & $4.5 \%$ \\
\hline \multirow{2}{*}{ Total } & 3550 & 3187 & 6691 & 6697 & 22,240 & 22,552 & 6937 & 6761 & 4994 & 4645 & 44,412 & 43,842 & 88,254 \\
\hline & $100.0 \%$ & $100.0 \%$ & $100.0 \%$ & $100.0 \%$ & $100.0 \%$ & $100.0 \%$ & $100.0 \%$ & $100.0 \%$ & $100.0 \%$ & $100.0 \%$ & $100.0 \%$ & $100.0 \%$ & $100.0 \%$ \\
\hline \multirow{3}{*}{ Women } & \multicolumn{12}{|c|}{ Deprivation Level (DL) $^{a}$} & \\
\hline & \multicolumn{2}{|c|}{ DL1 } & \multicolumn{2}{|c|}{ DL2 } & \multicolumn{2}{|c|}{ DL3 } & \multicolumn{2}{|c|}{ DL4 } & \multicolumn{2}{|c|}{ DL5 } & \multicolumn{2}{|c|}{ Total } & Total \\
\hline & $2000-2007$ & $2008-2015$ & $2000-2007$ & $2008-2015$ & $2000-2007$ & $2008-2015$ & $2000-2007$ & $2008-2015$ & $2000-2007$ & $2008-2015$ & $2000-2007$ & $2008-2015$ & \\
\hline \multirow{2}{*}{ I: Infectious and parasitic diseases } & 72 & 63 & 112 & 116 & 378 & 385 & 122 & 104 & 110 & 117 & 794 & 785 & 1579 \\
\hline & $2.0 \%$ & $1.6 \%$ & $1.6 \%$ & $1.5 \%$ & $1.8 \%$ & $1.7 \%$ & $2.0 \%$ & $1.6 \%$ & $2.5 \%$ & $2.8 \%$ & $1.9 \%$ & $1.8 \%$ & $1.8 \%$ \\
\hline \multirow{2}{*}{ II: Neoplasms } & 813 & 849 & 1610 & 1763 & 4504 & 5201 & 1339 & 1502 & 953 & 963 & 9219 & 10,278 & 19,497 \\
\hline & $22.3 \%$ & $22.0 \%$ & $22.5 \%$ & $23.3 \%$ & $21.7 \%$ & $23.0 \%$ & $21.8 \%$ & $23.4 \%$ & $22.0 \%$ & $23.0 \%$ & $21.9 \%$ & $23.0 \%$ & $22.5 \%$ \\
\hline \multirow{2}{*}{$\begin{array}{l}\text { III: Diseases of the blood, and } \\
\text { inmunity disorders }\end{array}$} & 14 & 20 & 26 & 40 & 98 & 95 & 20 & 32 & 21 & 23 & 179 & 210 & 389 \\
\hline & $0.4 \%$ & $0.5 \%$ & $0.4 \%$ & $0.5 \%$ & $0.5 \%$ & $0.4 \%$ & $0.3 \%$ & $0.5 \%$ & $0.5 \%$ & $0.5 \%$ & $0.4 \%$ & $0.5 \%$ & $0.4 \%$ \\
\hline \multirow{2}{*}{$\begin{array}{l}\text { IV: Endocrine, nutritional and } \\
\text { metabolic diseases }\end{array}$} & 104 & 104 & 251 & 224 & 737 & 798 & 271 & 242 & 183 & 170 & 1546 & 1538 & 3084 \\
\hline & $2.9 \%$ & $2.7 \%$ & $3.5 \%$ & $3.0 \%$ & $3.5 \%$ & $3.5 \%$ & $4.4 \%$ & $3.8 \%$ & $4.2 \%$ & $4.1 \%$ & $3.7 \%$ & $3.4 \%$ & $3.6 \%$ \\
\hline \multirow{2}{*}{ V: Mental and behavioural disorders } & 134 & 214 & 346 & 478 & 902 & 1249 & 239 & 358 & 163 & 255 & 1784 & 2554 & 4338 \\
\hline & $3.7 \%$ & $5.5 \%$ & $4.8 \%$ & $6.3 \%$ & $4.3 \%$ & $5.5 \%$ & $3.9 \%$ & $5.6 \%$ & $3.8 \%$ & $6.1 \%$ & $4.2 \%$ & $5.7 \%$ & $5.0 \%$ \\
\hline \multirow{2}{*}{$\begin{array}{l}\text { VI-VIII: Diseases of the nervous } \\
\text { system and organ senses }\end{array}$} & 184 & 303 & 351 & 636 & 1068 & 1793 & 310 & 485 & 205 & 314 & 2118 & 3531 & 5649 \\
\hline & $5.1 \%$ & $7.9 \%$ & $4.9 \%$ & $8.4 \%$ & $5.1 \%$ & $7.9 \%$ & $5.0 \%$ & $7.5 \%$ & $4.7 \%$ & $7.5 \%$ & $5.0 \%$ & $7.9 \%$ & $6.5 \%$ \\
\hline IX: Diseases of the circulatory system & 1474 & 1439 & 2861 & 2600 & 8171 & 7840 & 2403 & 2214 & 1642 & 1469 & 16,551 & 15,562 & 32,113 \\
\hline & $40.5 \%$ & $37.3 \%$ & $39.9 \%$ & $34.4 \%$ & $39.3 \%$ & $34.7 \%$ & $39.0 \%$ & $34.4 \%$ & $37.9 \%$ & $35.1 \%$ & $39.3 \%$ & $34.9 \%$ & $37.0 \%$ \\
\hline$X$ : Diseases of the respiratory system & 351 & 360 & 661 & 700 & 2080 & 2092 & 593 & 572 & 403 & 370 & 4088 & 4094 & 8182 \\
\hline & $9.6 \%$ & $9.3 \%$ & $9.2 \%$ & $9.3 \%$ & $10.0 \%$ & $9.3 \%$ & $9.6 \%$ & $8.9 \%$ & $9.3 \%$ & $8.8 \%$ & $9.7 \%$ & $9.2 \%$ & $9.4 \%$ \\
\hline
\end{tabular}


Table A5. Cont.

\begin{tabular}{|c|c|c|c|c|c|c|c|c|c|c|c|c|c|}
\hline \multirow{3}{*}{ Women } & \multicolumn{12}{|c|}{ Deprivation Level (DL) a } & \multirow{3}{*}{ Total } \\
\hline & \multicolumn{2}{|c|}{ DL1 } & \multicolumn{2}{|c|}{ DL2 } & \multicolumn{2}{|c|}{ DL3 } & \multicolumn{2}{|c|}{ DL4 } & \multicolumn{2}{|c|}{ DL5 } & \multicolumn{2}{|c|}{ Total } & \\
\hline & 2000-2007 & 2008-2015 & 2000-2007 & 2008-2015 & 2000-2007 & 2008-2015 & 2000-2007 & 2008-2015 & 2000-2007 & 2008-2015 & 2000-2007 & 2008-2015 & \\
\hline \multirow{2}{*}{ XI: Diseases of the digestive system } & 188 & 148 & 359 & 298 & 1106 & 1056 & 352 & 335 & 269 & 185 & 2274 & 2022 & 4296 \\
\hline & $5.2 \%$ & $3.8 \%$ & $5.0 \%$ & $3.9 \%$ & $5.3 \%$ & $4.7 \%$ & $5.7 \%$ & $5.2 \%$ & $6.2 \%$ & $4.4 \%$ & $5.4 \%$ & $4.5 \%$ & $5.0 \%$ \\
\hline \multirow{2}{*}{$\begin{array}{l}\text { XII: Diseases of the skin and } \\
\text { subcutaneous tissue }\end{array}$} & 13 & 22 & 24 & 37 & 94 & 129 & 35 & 40 & 22 & 14 & 188 & 242 & 430 \\
\hline & $0.4 \%$ & $0.6 \%$ & $0.3 \%$ & $0.5 \%$ & $0.5 \%$ & $0.6 \%$ & $0.6 \%$ & $0.6 \%$ & $0.5 \%$ & $0.3 \%$ & $0.4 \%$ & $0.5 \%$ & $0.5 \%$ \\
\hline \multirow{2}{*}{$\begin{array}{l}\text { XIII: Diseases of the musculoskeletal } \\
\text { system and connective tissue }\end{array}$} & 28 & 38 & 70 & 75 & 182 & 215 & 66 & 69 & 50 & 31 & 396 & 428 & 824 \\
\hline & $0.8 \%$ & $1.0 \%$ & $1.0 \%$ & $1.0 \%$ & $0.9 \%$ & $1.0 \%$ & $1.1 \%$ & $1.1 \%$ & $1.2 \%$ & $0.7 \%$ & $0.9 \%$ & $1.0 \%$ & $1.0 \%$ \\
\hline \multirow{2}{*}{$\begin{array}{l}\text { XIV: Diseases of the genitourinary } \\
\text { system }\end{array}$} & 114 & 134 & 217 & 270 & 607 & 837 & 166 & 227 & 141 & 136 & 1245 & 1604 & 2849 \\
\hline & $3.1 \%$ & $3.5 \%$ & $3.0 \%$ & $3.6 \%$ & $2.9 \%$ & $3.7 \%$ & $2.7 \%$ & $3.5 \%$ & $3.3 \%$ & $3.2 \%$ & $3.0 \%$ & $3.6 \%$ & $3.3 \%$ \\
\hline \multirow{2}{*}{$\begin{array}{l}\text { XV: Pregnancy, childbirth and the } \\
\text { puerperium }\end{array}$} & 0 & 0 & 0 & 2 & 2 & 3 & 1 & 1 & 0 & 0 & 3 & 6 & 9 \\
\hline & $0.0 \%$ & $0.0 \%$ & $0.0 \%$ & $0.0 \%$ & $0.0 \%$ & $0.0 \%$ & $0.0 \%$ & $0.0 \%$ & $0.0 \%$ & $0.0 \%$ & $0.0 \%$ & $0.0 \%$ & $0.0 \%$ \\
\hline \multirow{2}{*}{$\begin{array}{l}\mathrm{XVI} \text { : Certain conditions originating } \\
\text { in the perinatal period }\end{array}$} & 5 & 4 & 18 & 18 & 41 & 36 & 8 & 17 & 7 & 10 & 79 & 85 & 164 \\
\hline & $0.1 \%$ & $0.1 \%$ & $0.3 \%$ & $0.2 \%$ & $0.2 \%$ & $0.2 \%$ & $0.1 \%$ & $0.3 \%$ & $0.2 \%$ & $0.2 \%$ & $0.2 \%$ & $0.2 \%$ & $0.2 \%$ \\
\hline \multirow{2}{*}{ XVII: Congenital malformations } & 7 & 4 & 16 & 16 & 61 & 41 & 10 & 15 & 7 & 5 & 101 & 81 & 182 \\
\hline & $0.2 \%$ & $0.1 \%$ & $0.2 \%$ & $0.2 \%$ & $0.3 \%$ & $0.2 \%$ & $0.2 \%$ & $0.2 \%$ & $0.2 \%$ & $0.1 \%$ & $0.2 \%$ & $0.2 \%$ & $0.2 \%$ \\
\hline \multirow{2}{*}{$\begin{array}{l}\text { XVIII: Symptoms and signs not } \\
\text { elsewhere classified }\end{array}$} & 58 & 77 & 104 & 127 & 256 & 259 & 84 & 68 & 44 & 48 & 546 & 579 & 1125 \\
\hline & $1.6 \%$ & $2.0 \%$ & $1.5 \%$ & $1.7 \%$ & $1.2 \%$ & $1.1 \%$ & $1.4 \%$ & $1.1 \%$ & $1.0 \%$ & $1.1 \%$ & $1.3 \%$ & $1.3 \%$ & $1.3 \%$ \\
\hline \multirow{2}{*}{$\begin{array}{l}\text { XX: External causes of morbidity and } \\
\text { mortality }\end{array}$} & 80 & 79 & 142 & 167 & 485 & 561 & 137 & 146 & 112 & 76 & 956 & 1029 & 1985 \\
\hline & $2.2 \%$ & $2.0 \%$ & $2.0 \%$ & $2.2 \%$ & $2.3 \%$ & $2.5 \%$ & $2.2 \%$ & $2.3 \%$ & $2.6 \%$ & $1.8 \%$ & $2.3 \%$ & $2.3 \%$ & $2.3 \%$ \\
\hline \multirow{2}{*}{ Total } & 3639 & 3858 & 7168 & 7567 & 20,772 & 22,590 & 6156 & 6427 & 4332 & 4186 & 42,067 & 44,628 & 86,695 \\
\hline & $100.0 \%$ & $100.0 \%$ & $100.0 \%$ & $100.0 \%$ & $100.0 \%$ & $100.0 \%$ & $100.0 \%$ & $100.0 \%$ & $100.0 \%$ & $100.0 \%$ & $100.0 \%$ & $100.0 \%$ & $100.0 \%$ \\
\hline
\end{tabular}

Note: ${ }^{a}$ DL: Deprivation level of the census track of residence based on the deprivation index (DI). DL1: DI $<\mathrm{P}_{10}$; DL2: $\mathrm{P}_{10} \leq \mathrm{DI}<\mathrm{P}_{25}$; DL3: $\mathrm{P}_{25} \leq \mathrm{DI}<\mathrm{P}_{75}$; DL4: $\mathrm{P}_{75} \leq \mathrm{DI}<\mathrm{P}_{90}$; DL5: DI $\geq$

$\mathrm{P}_{90} . \mathrm{P}_{\mathrm{q}}=$ Percentile $\mathrm{q}$ 
Table A6. Mortality rates $(\times 100,000)$ for all causes, by sex, age group, deprivation level, and period under study. All cities together.

\begin{tabular}{|c|c|c|c|c|}
\hline \multirow{2}{*}{ Sex } & \multirow{2}{*}{ Age } & \multirow{2}{*}{ Deprivation Level (DL) $^{a}$} & \multicolumn{2}{|c|}{ Period } \\
\hline & & & 2000-2007 & 2008-2015 \\
\hline \multirow{15}{*}{ Men } & \multirow{5}{*}{$0-44$} & DL1 & 77.3 & 55.7 \\
\hline & & DL2 & 90.3 & 49.1 \\
\hline & & DL3 & 92.4 & 57.9 \\
\hline & & DL4 & 116.3 & 76.0 \\
\hline & & DL5 & 157.3 & 88.1 \\
\hline & \multirow{5}{*}{$45-64$} & DL1 & 580.8 & 501.0 \\
\hline & & DL2 & 586.1 & 436.5 \\
\hline & & DL3 & 678.1 & 574.0 \\
\hline & & DL4 & 797.1 & 715.1 \\
\hline & & DL5 & 985.8 & 769.3 \\
\hline & \multirow{5}{*}{$\geq 65$} & DL1 & 5215.2 & 4324.3 \\
\hline & & DL2 & 5105.4 & 4383.7 \\
\hline & & DL3 & 5125.3 & 4617.4 \\
\hline & & DL4 & 5021.5 & 4908.0 \\
\hline & & DL5 & 5291.3 & 5301.7 \\
\hline \multirow{15}{*}{ Women } & \multirow{5}{*}{$0-44$} & DL1 & 39.5 & 26.5 \\
\hline & & DL2 & 42.4 & 29.0 \\
\hline & & DL3 & 45.1 & 34.3 \\
\hline & & DL4 & 52.4 & 37.7 \\
\hline & & DL5 & 61.5 & 51.2 \\
\hline & \multirow{5}{*}{$45-64$} & DL1 & 242.9 & 253.2 \\
\hline & & DL2 & 270.2 & 223.2 \\
\hline & & DL3 & 267.6 & 250.3 \\
\hline & & DL4 & 306.6 & 303.4 \\
\hline & & DL5 & 357.7 & 347.5 \\
\hline & \multirow{5}{*}{$\geq 65$} & DL1 & 3690.7 & 3663.7 \\
\hline & & DL2 & 4010.4 & 3751.5 \\
\hline & & DL3 & 3676.7 & 3584.8 \\
\hline & & DL4 & 3745.6 & 3611.7 \\
\hline & & DL5 & 3691.3 & 3700.3 \\
\hline
\end{tabular}

Note: a DL: Deprivation level of the census track of residence based on the deprivation index (DI). DL1: DI $<\mathrm{P}_{10}$; DL2: $\mathrm{P}_{10} \leq \mathrm{DI}<\mathrm{P}_{25}$; DL3: $\mathrm{P}_{25} \leq$ DI $<\mathrm{P}_{75} ;$ DL4: $\mathrm{P}_{75} \leq \mathrm{DI}<\mathrm{P}_{90}$; DL5: DI $\geq \mathrm{P}_{90}$. $\mathrm{P}_{\mathrm{q}}=$ Percentile $\mathrm{q}$.

Table A7. Mortality rates $(\times 100,000)$ by susceptible causes, sex, age group, level of deprivation, and period of study. All cities together.

\begin{tabular}{|c|c|c|c|c|}
\hline \multirow{2}{*}{ Sex } & \multirow{2}{*}{ Age } & \multirow{2}{*}{ Deprivation Level (DL) $^{a}$} & \multicolumn{2}{|c|}{ Period } \\
\hline & & & 2000-2007 & 2008-2015 \\
\hline \multirow{15}{*}{ Men } & \multirow{5}{*}{$0-44$} & DL1 & 18.1 & 10.8 \\
\hline & & DL2 & 17.7 & 9.6 \\
\hline & & DL3 & 15.1 & 11.5 \\
\hline & & DL4 & 15.7 & 15.3 \\
\hline & & DL5 & 18.0 & 13.6 \\
\hline & \multirow{5}{*}{$45-64$} & DL1 & 91.3 & 96.7 \\
\hline & & DL2 & 114.4 & 74.9 \\
\hline & & DL3 & 122.7 & 101.4 \\
\hline & & DL4 & 136.1 & 142.6 \\
\hline & & DL5 & 189.7 & 131.9 \\
\hline & \multirow{5}{*}{$\geq 65$} & DL1 & 316.1 & 202.3 \\
\hline & & DL2 & 316.9 & 194.1 \\
\hline & & DL3 & 347.3 & 225.0 \\
\hline & & DL4 & 344.6 & 262.4 \\
\hline & & DL5 & 371.9 & 250.4 \\
\hline
\end{tabular}


Table A7. Cont.

\begin{tabular}{|c|c|c|c|c|}
\hline \multirow{2}{*}{ Sex } & \multirow{2}{*}{ Age } & \multirow{2}{*}{ Deprivation Level (DL) $^{a}$} & \multicolumn{2}{|c|}{ Period } \\
\hline & & & 2000-2007 & 2008-2015 \\
\hline \multirow{15}{*}{ Women } & \multirow{5}{*}{$0-44$} & DL1 & 10.2 & 9.7 \\
\hline & & DL2 & 13.7 & 12.3 \\
\hline & & DL3 & 13.9 & 11.2 \\
\hline & & DL4 & 17.1 & 13.7 \\
\hline & & DL5 & 15.4 & 18.8 \\
\hline & \multirow{5}{*}{$45-64$} & DL1 & 95.2 & 72.9 \\
\hline & & DL2 & 105.6 & 75.3 \\
\hline & & DL3 & 96.7 & 80.9 \\
\hline & & DL4 & 109.8 & 100.4 \\
\hline & & DL5 & 128.3 & 123.5 \\
\hline & \multirow{5}{*}{$\geq 65$} & DL1 & 134.0 & 91.3 \\
\hline & & DL2 & 142.4 & 119.5 \\
\hline & & DL3 & 167.7 & 124.9 \\
\hline & & DL4 & 185.4 & 127.3 \\
\hline & & DL5 & 223.2 & 152.1 \\
\hline
\end{tabular}

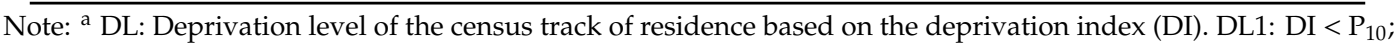
DL2: $\mathrm{P}_{10} \leq \mathrm{DI}<\mathrm{P}_{25}$; DL3: $\mathrm{P}_{25} \leq$ DI $<\mathrm{P}_{75}$; DL4: $\mathrm{P}_{75} \leq \mathrm{DI}<\mathrm{P}_{90}$; DL5: DI $\geq \mathrm{P}_{90} . \mathrm{P}_{\mathrm{q}}=$ Percentile $\mathrm{q}$.

Table A8. Relative risks of death by amenable causes of death (excluding ischemic heart disease) according to deprivation level and $95 \%$ confidence intervals (95\% CI) by age, sex, and period. All cities together.

\begin{tabular}{|c|c|c|c|c|c|c|c|c|}
\hline \multirow{3}{*}{ Sex } & \multirow{3}{*}{ Age } & \multirow{3}{*}{ Deprivation Level (DL) ${ }^{a}$} & \multicolumn{3}{|c|}{ 2000-2007 } & \multicolumn{3}{|c|}{ 2008-2015 } \\
\hline & & & \multirow{2}{*}{$\mathbf{R R}$} & \multicolumn{2}{|c|}{$95 \%$ CI } & \multirow[t]{2}{*}{ RR } & \multicolumn{2}{|c|}{$95 \% \mathrm{CI}$} \\
\hline & & & & Lower & Upper & & Lower & Upper \\
\hline \multirow{15}{*}{ Men } & \multirow{5}{*}{$0-44$} & DL5 & 1.013 & 0.660 & 1.568 & 1.369 & 0.768 & 1.369 \\
\hline & & DL4 & 0.765 & 0.508 & 1.166 & 1.525 & 0.896 & 1.525 \\
\hline & & DL3 & 0.789 & 0.564 & 1.137 & 1.129 & 0.697 & 1.129 \\
\hline & & DL2 & 0.961 & 0.655 & 1.434 & 0.959 & 0.555 & 0.959 \\
\hline & & DL1 & 1.000 & & & 1.000 & & \\
\hline & \multirow{5}{*}{$45-64$} & DL5 & 2.270 & 1.667 & 3.128 & 1.324 & 0.953 & 1.324 \\
\hline & & DL4 & 1.499 & 1.111 & 2.051 & 1.586 & 1.186 & 1.586 \\
\hline & & DL3 & 1.333 & 1.022 & 1.773 & 1.106 & 0.850 & 1.106 \\
\hline & & DL2 & 1.290 & 0.956 & 1.765 & 0.784 & 0.575 & 0.784 \\
\hline & & DL1 & 1.000 & & & 1.000 & & \\
\hline & \multirow{5}{*}{$\geq 65$} & DL5 & 1.269 & 1.010 & 1.601 & 1.179 & 0.912 & 1.179 \\
\hline & & DL4 & 1.167 & 0.940 & 1.457 & 1.223 & 0.968 & 1.223 \\
\hline & & DL3 & 1.134 & 0.939 & 1.384 & 1.029 & 0.839 & 1.029 \\
\hline & & DL2 & 1.009 & 0.808 & 1.266 & 0.865 & 0.679 & 0.865 \\
\hline & & DL1 & 1.000 & & & 1.000 & & \\
\hline \multirow{15}{*}{ Women } & \multirow{5}{*}{$0-44$} & DL5 & 1.534 & 0.913 & 2.639 & 2.014 & 1.196 & 3.549 \\
\hline & & DL4 & 1.675 & 1.054 & 2.770 & 1.379 & 0.823 & 2.420 \\
\hline & & DL3 & 1.426 & 0.942 & 2.274 & 1.141 & 0.723 & 1.920 \\
\hline & & DL2 & 1.490 & 0.940 & 2.459 & 1.230 & 0.747 & 2.134 \\
\hline & & DL1 & 1.000 & & & 1.000 & & \\
\hline & \multirow{5}{*}{$45-64$} & DL5 & 1.387 & 1.061 & 1.818 & 1.521 & 1.155 & 2.012 \\
\hline & & DL4 & 1.205 & 0.945 & 1.547 & 1.218 & 0.942 & 1.587 \\
\hline & & DL3 & 1.042 & 0.846 & 1.298 & 1.003 & 0.804 & 1.268 \\
\hline & & DL2 & 1.102 & 0.869 & 1.408 & 0.958 & 0.746 & 1.241 \\
\hline & & DL1 & 1.000 & & & 1.000 & & \\
\hline & \multirow{5}{*}{$\geq 65$} & DL5 & 1.613 & 1.281 & 2.044 & 1.796 & 1.356 & 2.398 \\
\hline & & DL4 & 1.377 & 1.101 & 1.733 & 1.530 & 1.173 & 2.018 \\
\hline & & DL3 & 1.217 & 1.000 & 1.498 & 1.561 & 1.235 & 2.004 \\
\hline & & DL2 & 1.052 & 0.835 & 1.333 & 1.432 & 1.100 & 1.885 \\
\hline & & DL1 & 1.000 & & & 1.000 & & \\
\hline
\end{tabular}

Note: ${ }^{a}$ DL: Deprivation level of the census track of residence based on the deprivation index (DI). DL1: DI $<\mathrm{P}_{10}$; DL2: $\mathrm{P}_{10} \leq \mathrm{DI}<\mathrm{P}_{25} ;$ DL3: $\mathrm{P}_{25} \leq \mathrm{DI}<\mathrm{P}_{75} ; \mathrm{DL} 4: \mathrm{P}_{75} \leq \mathrm{DI}<\mathrm{P}_{90} ; \mathrm{DL} 5:$ DI $\geq \mathrm{P}_{90}$. $\mathrm{P}_{\mathrm{q}}=$ Percentile $\mathrm{q}$. 
Table A9. Relative risks of death by amenable causes (excluding ischemic heart disease) for the period 2008-2015 as compared to the period 2000-2007 and 95\% confidence intervals (95\% CI) by age, sex, and deprivation level. All cities together.

\begin{tabular}{|c|c|c|c|c|c|c|c|}
\hline \multirow{3}{*}{ Deprivation Level (DL) $^{a}$} & \multirow{3}{*}{ Age } & \multicolumn{3}{|c|}{ Men } & \multicolumn{3}{|c|}{ Women } \\
\hline & & \multirow{2}{*}{$\mathbf{R R}$} & \multicolumn{2}{|c|}{$95 \% \mathrm{CI}$} & \multirow{2}{*}{ RR } & \multicolumn{2}{|c|}{$95 \% \mathrm{CI}$} \\
\hline & & & Lower & Upper & & Lower & Upper \\
\hline \multirow{3}{*}{ DL1 } & $0-44$ & 0.517 & 0.280 & 0.912 & 0.997 & 0.528 & 1.855 \\
\hline & $45-64$ & 1.041 & 0.722 & 1.503 & 0.888 & 0.663 & 1.187 \\
\hline & $\geq 65$ & 0.773 & 0.591 & 1.008 & 0.623 & 0.461 & 0.836 \\
\hline \multirow{3}{*}{ DL2 } & $0-44$ & 0.516 & 0.357 & 0.739 & 0.823 & 0.588 & 1.151 \\
\hline & $45-64$ & 0.633 & 0.496 & 0.805 & 0.772 & 0.634 & 0.939 \\
\hline & $\geq 65$ & 0.663 & 0.543 & 0.808 & 0.848 & 0.697 & 1.031 \\
\hline \multirow{3}{*}{ DL3 } & $0-44$ & 0.740 & 0.600 & 0.909 & 0.798 & 0.652 & 0.975 \\
\hline & $45-64$ & 0.864 & 0.761 & 0.982 & 0.855 & 0.762 & 0.959 \\
\hline & $\geq 65$ & 0.701 & 0.632 & 0.777 & 0.799 & 0.719 & 0.887 \\
\hline \multirow{3}{*}{ DL4 } & $0-44$ & 1.030 & 0.710 & 1.494 & 0.820 & 0.570 & 1.175 \\
\hline & $45-64$ & 1.102 & 0.885 & 1.374 & 0.897 & 0.728 & 1.106 \\
\hline & $\geq 65$ & 0.810 & 0.675 & 0.970 & 0.692 & 0.571 & 0.838 \\
\hline \multirow{3}{*}{ DL5 } & $0-44$ & 0.698 & 0.446 & 1.082 & 1.309 & 0.857 & 2.018 \\
\hline & $45-64$ & 0.608 & 0.461 & 0.798 & 0.974 & 0.755 & 1.256 \\
\hline & $\geq 65$ & 0.718 & 0.574 & 0.895 & 0.693 & 0.557 & 0.860 \\
\hline
\end{tabular}

Note: ${ }^{a}$ DL: Deprivation level for the census track of residence based on the deprivation index (DI). DL1: DI $<\mathrm{P}_{10}$; DL2: $\mathrm{P}_{10} \leq \mathrm{DI}<\mathrm{P}_{25} ;$ DL3: $\mathrm{P}_{25} \leq \mathrm{DI}<\mathrm{P}_{75}$; DL4: $\mathrm{P}_{75} \leq \mathrm{DI}<\mathrm{P}_{90}$; DL5: DI $\geq \mathrm{P}_{90} . \mathrm{P}_{\mathrm{q}}=$ Percentile $\mathrm{q}$.

\section{References}

1. Nolte, E.; McKee, M. Does Healthcare Save Lives? Avoidable Mortality Revisited; The Nuffield Trust: London, UK, 2004; Available online: https://researchonline.lshtm.ac.uk/id/eprint/15535 (accessed on 27 July 2020).

2. Nolte, E.; McKee, M. Variations in amenable mortality-Trends in 16 high-income nations. Health Policy 2011, 103, 47-52. Available online: https://doi.org/10.1016/j.healthpol.2011.08.002 (accessed on 27 July 2020). [CrossRef]

3. United Nations. Department of Economic and Social Affairs. Changing Levels and Trends in Mortality: The Role of Patterns of Death by Cause. 2012. Available online: https://www.un.org/en/ (accessed on 27 July 2020).

4. MacKenbach, J.P.; Hu, Y.; Artnik, B.; Bopp, M.; Costa, G.; Kalediene, R.; Martikainen, P.; Menvielle, G.; Strand, B.H.; Wojtyniak, B.; et al. Trends in inequalities in mortality amenable to health care in 17 european countries. Health Aff. 2017, 36, 1110-1118. [CrossRef]

5. Weber, A.; Clerc, M. Deaths amenable to health care: Converging trends in the EU? Health Policy 2017, 121, 644-652. [CrossRef] [PubMed]

6. Nolasco, A.; Pereyra-Zamora, P.; Sanchis-Matea, E.; Fonseca, N.T.; Caballero, P.; Melchor, I.; Moncho, J. Economic crisis and amenable mortality in Spain. Int. J. Environ. Res. Public Health 2018, 15, 2298. [CrossRef] [PubMed]

7. Karanikolos, M.; Mackenbach, J.P.; Nolte, E.; Stuckler, D.; McKee, M. Amenable mortality in the EU-has the crisis changed its course? Eur. J. Public Health 2018, 28, 864-869. [CrossRef] [PubMed]

8. Suhrcke, M.; Stuckler, D. Will the recession be bad for our health? It depends. Soc. Sci. Med. 2012, 74, 647-653. [CrossRef]

9. Miller, D.L.; Page, M.E.; Stevens, A.H.; Filipski, M. Why are recessions good for your health? Am. Econ. Rev. 2009, 99, 122-127. [CrossRef]

10. Van Den Berg, G.J.; Lindeboom, M.; López, M. IZA DP No.2425: Inequality in individual mortality and economic conditions earlier in life. Soc. Sci. Med. 2009, 69, 1360-1367. [CrossRef]

11. Bacigalupe, A.; Shahidi, F.V.; Muntaner, C.; Martín, U.; Borrell, C. Why is there so much controversy regarding the population health impact of the great recession? Reflections on three case studies. Int. J. Health Serv. 2016, 46, 5-35. [CrossRef] 
12. Neumayer, E. Recessions lower (some) mortality rates: Evidence from Germany. Soc. Sci. Med. 2004, 58, 1037-1047. [CrossRef]

13. Tapia Granados, J.A.; House, J.S.; Ionides, E.L.; Burgard, S.; Schoeni, R.S. Individual joblessness, contextual unemployment, and mortality risk. Am. J. Epidemiol. 2014, 180, 280-287. [CrossRef] [PubMed]

14. Márquez-Calderón, S.; Pérez Velasco, L.; Viciana-Fernández, F.; Fernández Merino, J.C. Trends in age-sex-specific mortality in Spain (1981-2016). Changes associated with the economic crisis. Gac. Sanit. 2019, 34, 230-237. [CrossRef] [PubMed]

15. Gotsens, M.; Ferrando, J.; Marí-Dell'Olmo, M.; Palencia, L.; Bartoll, X.; Gandarillas, A.; Sánchez-Villegas, P.; Esnaola, S.; Daponte-Codina, A.; Borrell, C. Effect of the financial crisis on socioeconomic inequalities in mortality in small areas in seven Spanish cities. Int. J. Environ. Res. Public Health 2020, 17, 958. [CrossRef] [PubMed]

16. Alvarez-Galvez, J.; Suarez-Lledo, V.; Martinez-Cousinou, G.; Muniategui-Azkona, E.; Gonzalez-Portillo, A. The impact of financial crisis and austerity policies in Andalusia, Spain: Disentangling the mechanisms of social inequalities in health through the perceptions and experiences of experts and the general population. Int. J. Equity Health 2019, 18, 1-12. [CrossRef] [PubMed]

17. Parmar, D.; Stavropoulou, C.; Ioannidis, J.P.A. Health outcomes during the 2008 financial crisis in Europe: Systematic literature review. BMJ 2016, 354, i4588. [CrossRef] [PubMed]

18. Karanikolos, M.; Mladovsky, P.; Cylus, J.; Thomson, S.; Basu, S.; Stuckler, D.; MacKenbach, J.P.; McKee, M. Financial crisis, austerity, and health in Europe. Lancet 2013, 381, 1323-1331. [CrossRef]

19. Palencia, L.; Gotsens, M.; Marí-Dell'Olmo, M.; Bosakova, L.; Burström, B.; Costa, C.; Deboosere, P.; Dzurova, D.; Lustigova, M.; Morrison, J.; et al. Effect of the recent economic crisis on socioeconomic inequalities in mortality in nine urban areas in Europe. Gac. Sanit. 2020, 34, 253-260. [CrossRef]

20. Strumpf, E.C.; Charters, T.J.; Harper, S.; Nandi, A. Did the great recession affect mortality rates in the metropolitan United States? Effects on mortality by age, gender and cause of death. Soc. Sci. Med. 2017, 189, 11-16. [CrossRef]

21. Hone, T.; Mirelman, A.J.; Rasella, D.; Paes-Sousa, R.; Barreto, M.L.; Rocha, R.; Millett, C. Effect of economic recession and impact of health and social protection expenditures on adult mortality: A longitudinal analysis of 5565 Brazilian municipalities. Lancet Glob. Health 2019, 7, e1575-e1583. [CrossRef]

22. Nolasco, A.; Vicent-Castelló, E.M.; Pereyra-Zamora, P.; Caballero-Pérez, P.; Moncho, J. Mortality due to medical and surgical complications, economic crisis and health spending in Spain, 2002-2013. Gac. Sanit. 2019, 33, 504-510. [CrossRef]

23. Christos, Z.; Stuckler, D.; McKee, M. Use of amenable mortality indicators to evaluate the impact of financial crisis on health system performance in Greece. Eur. J. Public Health 2020, ckaa058, 1-6. [CrossRef]

24. Rodríguez-Sanz, M.; Santisteve, P.C.; Borrell, C. Desigualdades Sociales en la Salud, Los Estilos de Vida y la Utilización de Servicios Sanitarios en Las Comunidades Autónomas, 1993-2003; Agencia de Salud Pública de Barcelona: Barcelona, España, 2006; Available online: https://www.mscbs.gob.es/en/ (accessed on 27 July 2020).

25. Carstairs, V.; Morris, R. Deprivation and health in Scotland. Health Bull. (Edinb) 1990, 48, 162-175. Available online: https://pubmed.ncbi.nlm.nih.gov/2394583/ (accessed on 27 July 2020). [PubMed]

26. Domínguez, Á.; Borrell, C.; Cano-Serral, G.; Esnaola, S.; Nolasco, A.; Pasarín, M.I.; Ramis, R.; Saurina, C.; Escolar-Pujolar, A. Construcción de un índice de privación a partir de datos censales en grandes ciudades españolas (Proyecto MEDEA). Gac. Sanit. 2008, 22, 179-187. [CrossRef] [PubMed]

27. Nolasco, A.; Quesada, J.A.; Moncho, J.; Melchor, I.; Pereyra-Zamora, P.; Fonseca, N.T.; Martínez-Beneito, M.A.; Zurriaga, $\mathrm{O}$. Trends in socioeconomic inequalities in amenable mortality in urban areas of Spanish cities, 1996-2007. BMC Public Health 2014, 14, 1-12. [CrossRef]

28. Nolasco, A.; Moncho, J.; Quesada, J.A.; Melchor, I.; Pereyra-Zamora, P.; Fonseca, N.T.; Martínez-Beneito, M.A.; Zurriaga, O.; Ballesta, M.; Daponte-Codina, A.; et al. Trends in socioeconomic inequalities in preventable mortality in urban areas of 33 Spanish cities, 1996-2007 (MEDEA project). Int. J. Equity Health 2015, 14, 1-15. [CrossRef]

29. Hoogenboom-Plug, I.; Hoffmann, R.; Artnik, B.; Bopp, M.; Borrell, C.; Costa, G.; Deboosere, P.; Esnaola, S.; Kalediene, R.; Leinsalu, M.; et al. Socioeconomic inequalities in mortality from conditions amenable to medical interventions: Do they reflect inequalities in access or quality of health care? BMC Public Health 2012, 12, 1-13. [CrossRef] 
30. Feller, A.; Schmidlin, K.; Clough-Gorr, K.M. Trends and socioeconomic inequalities in amenable mortality in Switzerland with international comparisons. Swiss Med. Wkly. 2007, 147, w14478. [CrossRef]

31. Nolte, E.; McKee, M. Measuring the health of nations: Updating an earlier analysis. Health Aff. 2008, 27, 58-71. [CrossRef]

32. Tapia Granados, J.A. Recessions and mortality in Spain, 1980-1997. Eur. J. Popul. 2005, 21, 393-422. [CrossRef]

33. Catalano, R.; Goldman-Mellor, S.; Saxton, K.B.; Margerison-Zilko, C.E.; Subbaraman, M.S.; LeWinn, K.Z.; Anderson, E. The Health effects of economic decline. Annu.. Rev. Public Health 2011, 32, 431-450. [CrossRef]

34. Romero, C.C.; Gutiérrez, J.C.S.; Aguado, L.Q.; Arcas, M.V.C.; Blázquez, J.A.P.; Méndez, J.A.G.; Bonacho, E.C.; Quintela, Y.A.G. Prevalencia de consumo de tabaco en población trabajadora tras la entrada en vigor de la Ley 42/2010. Rev. Esp. Salud Publica 2013, 87, 177-188.

35. Dávila Quintana, C.D.; González López-Valcárcel, B. Crisis económica y salud. Gac. Sanit. 2009, 23, 261-265. [CrossRef] [PubMed]

36. Bender, K.A.; Economou, A.; Theodossiou, I. The temporary and permanent effects of unemployment on mortality in Europe. Int. Labour Rev. 2013, 152, 275-286. [CrossRef]

37. Fondo de Desarrollo de las Naciones Unidas Para la Mujer. CEPAL-UNIFEM. Entender la Pobreza Desde la Perspectiva de Género. 2004. Available online: https://repositorio.cepal.org/handle/11362/5918 (accessed on 27 July 2020).

38. McCallum, A.K.; Manderbacka, K.; Arffman, M.; Leyland, A.H.; Keskimäki, I. Socioeconomic differences in mortality amenable to health care among Finnish adults 1992-2003: 12 year follow up using individual level linked population register data. BMC Health Serv. Res. 2013, 13, 1-12. [CrossRef]

39. Tapia Granados, J.A.; Rodriguez, J.M. Health, economic crisis, and austerity: A comparison of Greece, Finland and Iceland. Health Policy 2015, 119, 941-953. [CrossRef] [PubMed]

40. Ley 42/2010, de 30 de Diciembre, Por la Que se Modifica la Ley 28/2005, de 26 de Diciembre, de Medidas Sanitarias Frente al Tabaquismo y Reguladora de la Venta, el Suministro, el Consumo y la Publicidad de Los Productos Del Tabaco. BOE no. 318. 31 December 2010. Available online: https://www.boe.es/buscar/doc. php?id=BOE-A-2010-20138 (accessed on 27 July 2020).

41. Novoa, A.M.; Ward, J.; Malmusi, D.; Díaz, F.; Darnell, M.; Trilla, C.; Bosch, J.; Borrell, C. How substandard dwellings and housing affordability problems are associated with poor health in a vulnerable population during the economic recession of the late 2000s. Int. J. Equity Health 2015, 14, 120. [CrossRef]

42. Manderbacka, K.; Arffman, M.; Sund, R.; Karvonen, S. Multiple social disadvantage does it have an effect on amenable mortality: A brief report. Int. J. Equity Health 2014, 13, 1-7. [CrossRef]

43. Real Decreto-Ley 16/2012, de 20 de Abril, de Medidas Urgentes para Garantizar la Sostenibilidad del Sistema Nacional de Salud y Mejorar la Calidad y Seguridad de sus Prestaciones. BOE no. 98. 24 April 2012. Available online: https://www.boe.es/buscar/doc.php?id=BOE-A-2012-5403 (accessed on 27 July 2020).

44. Deandrea, S.; Molina-Barceló, A.; Uluturk, A.; Moreno, J.; Neamțiu, L.; Peiró-Pérez, R.; Parkinson, Z.S.; Lopez-Alcalde, J.; Lerda, D.; Salas, D. Presence, characteristics and equity of access to breast cancer screening programmes in 27 European countries in 2010 and 2014. Results from an international survey. Prev. Med. 2016, 91, 250-263. [CrossRef]

45. Molina-Barceló, A.; Salas-Trejo, D.; Peiró-Pérez, R.; Vanaclocha, M.; Pérez, E.; Castán, S. Reasons for participating in the Valencian Community Colorectal Cancer Screening Programme by gender, age, and social class. Rev. Esp. Enferm. Dig. 2014, 106, 439-447.

46. Plug, I.; Hoffmann, R.; Khoshaba, B.; Westerling, R.; Jougla, E.; Rey, G.; Mckee, M.; Mackenbach, J. AMIEHS, avoidable mortality in the European Union: Towards better indicators for the effectiveness of health systems. Eur. J. Public Health 2010, 20, 93.

(C) 2020 by the authors. Licensee MDPI, Basel, Switzerland. This article is an open access article distributed under the terms and conditions of the Creative Commons Attribution (CC BY) license (http://creativecommons.org/licenses/by/4.0/). 